\title{
Hydraulic Analysis of
}

U.S. Highway 59 Crossing of the Neosho River near Erie, Southeast Kansas

By PATRICK P. RASMUSSEN and CHARLES A. PERRY

Open-File Report 00-210

Prepared in cooperation with the KANSAS DEPARTMENT OF TRANSPORTATION 


\section{U.S. Department of the Interior}

Bruce Babbitt, Secretary

\section{U.S. Geological Survey}

Charles G. Groat, Director

For additional information write to:

District Chief

U.S. Geological Survey 4821 Quail Crest Place

Lawrence, KS 66049-3839
Copies of this report can be purchased from:

U.S. Geological Survey

Information Services

Building 810 , Federal Center

Box 25286

Denver, CO 80225-0286 


\section{CONTENTS}

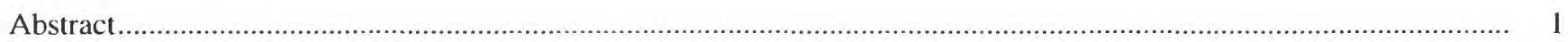

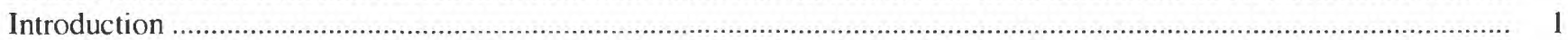

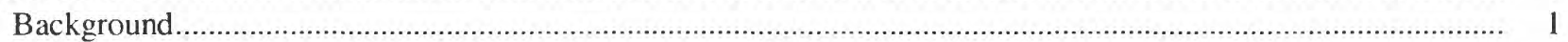

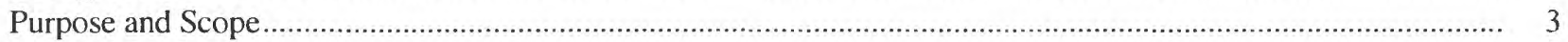

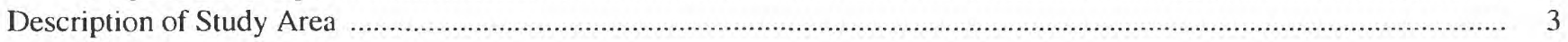

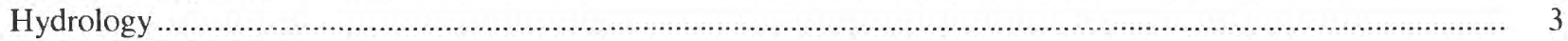

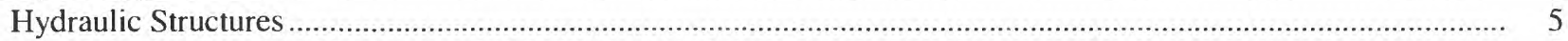

Existing Alignment and Features of U.S. Highway 59 ............................................................................. 5

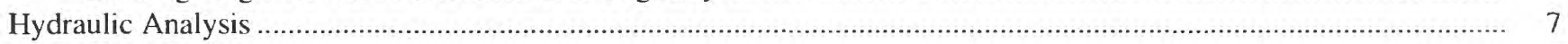

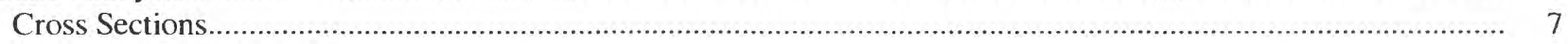

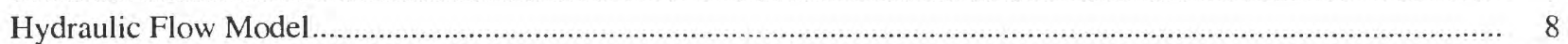

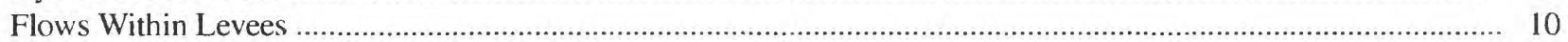

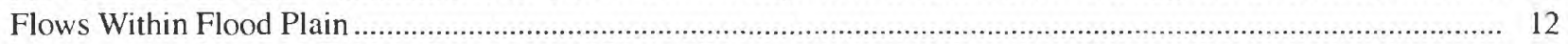

Flows Within Channel, Bridge Opening, and Levee Changes .................................................................. 13

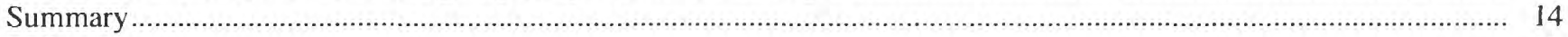

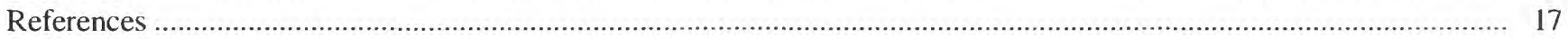

\section{FIGURES}

1-2. Maps showing:

1. Location of Neosho River Basin and pertinent features within the basin ................................................ 2

2. Location of surveyed cross sections along Neosho River in vicinity of Erie, Kansas...................................... 4

3. Photographs showing overflow dam just downstream from old U.S. Highway 59 bridge,

old U.S. Highway 59 bridge, and new U.S. Highway 59 bridge at Erie, Kansas ................................

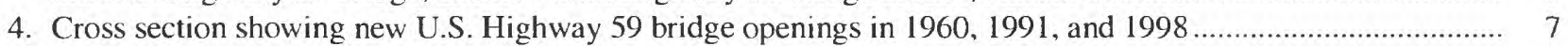

5-12. Cross section:

5. A across Neosho River near Erie, Kansas, 1999, with water-surface elevations for discharges of 37,000 and 82,000 cubic feet per second.

6. B across Neosho River near Erie, Kansas, 1999, with water-surface elevations for discharges of 37,000 and 82,000 cubic feet per second..

7. C and old U.S. Highway 59 roadway profile across Neosho River near Erie, Kansas, 1999, and flow-structure opening with water-surface elevations for discharges of 37,000 and 82,000 cubic feet per second

$\left(\frac{10}{10}\right.$

(1)

(1)

7

8. D across Neosho River near Erie, Kansas, 1999, with water-surface elevations for discharges of 37,000 and 82,000 cubic feet per second.......

9. E across Neosho River near Erie, Kansas, 1999, with water-surface elevations for discharges of 37,000 and 82,000 cubic feet per second...

10. F and new U.S. Highway 59 roadway profile across Neosho River near Erie, Kansas, 1999, and flow-structure opening with water-surface elevations for discharges of 37.000 and 82.000 cubic feet per second

11. G across Neosho River near Erie, Kansas, 1999, with water-surface elevations for discharges of 37,000 and 82,000 cubic feet per second..

12. H across Neosho River near Erie, Kansas, 1999, with water-surface elevations for discharges of 37,000 and 82,000 cubic feet per second.

13-16. Graphs showing:

13. Simulated water-surface elevations using 1960 bridge-opening data for Neosho River near Erie, Kansas, for various flood discharges within levees. 


\section{FIGURES-Continued}

14. Simulated water-surface elevations for flood of October 1986 within flood plain, Neosho River near Erie, Kansas

15. Land-surface elevations for cross section G before 1971, after 1971, and for hypothetical changes.

16. Simulated water-surface elevations at a discharge of 37,000 cubic feet per second for Neosho River near Erie, Kansas, for flow through a hypothetical relief structure

\section{TABLE}

1. Water-surface elevations, in feet above sea level, at selected locations simulating various modifications to hydraulic structures at discharges of $37,000,82,000$, and 111,000 cubic feet per second

CONVERSION FACTORS, ABBREVIATIONS, AND

VERTICAL DATUM

\begin{tabular}{rll}
\hline Multiply & By & To obtain \\
\hline cubic foot per second $\left(\mathrm{ft}^{3} / \mathrm{s}\right)$ & 0.02832 & cubic meter per second \\
cubic yard $\left(\mathrm{yd}^{3}\right)$ & 0.7646 & cubic meter \\
foot $(\mathrm{ft})$ & 0.3048 & meter \\
foot per mile $(\mathrm{ft} / \mathrm{mi})$ & 0.1894 & meter per kilometer \\
inch (in.) & 25.4 & millimeter \\
mile $(\mathrm{mi})$ & 1.609 & kilometer \\
square foot $\left(\mathrm{ft}^{2}\right)$ & 0.09290 & square meter \\
square mile $\left(\mathrm{mi}^{2}\right)$ & 2.590 & square kilometer \\
\hline
\end{tabular}

Sea level: In this report, "sea level" refers to the National Geodetic Vertical Datum of 1929- a geodetic datum derived from a general adjustment of the first-order level nets of the United States and Canada, formerly called Sea Level Datum of 1929 


\title{
Hydraulic Analysis of U.S. Highway 59 Crossing of the Neosho River near Erie, Southeast Kansas
}

\author{
By Patrick P. Rasmussen and Charles A. Perry
}

\begin{abstract}
The reach of the Neosho River used for the hydraulic analysis of the U.S. Highway 59 crossing in the vicinity of Erie in southeast Kansas is complicated by several factors, including a railroad crossing, an overflow dam, two major highway crossings (old and new U.S. Highway 59), and several levees on both sides of the river. These structures affect the backwater characteristics of the Neosho River and its tributaries in various ways that depend upon the magnitude of stream discharge.
\end{abstract}

A hydraulic analysis of the Neosho River in the vicinity of U.S. Highway 59 crossing near Erie was conducted using a step-backwater model (WSPRO). Model simulations of water-surface elevations for present conditions indicate that the levees in the vicinity of the new U.S. Highway 59 bridge begin to be overtopped when the discharge is greater than 37,000 cubic feet per second. At discharges of 82,000 and 111,000 cubic feet per second the entire river valley conveys water, and the backwater from the U.S. Highway 59 bridge embankment is about 1.0 and 1.2 feet deep for the respective discharges.

Various modifications to the hydraulic structures in the Neosho River Valley in the vicinity of the U.S. Highway 59 crossing were simulated using WSPRO. Model simulations indicate that the problem of levee overtopping upstream from the new U.S. Highway 59 bridge over the Neosho River does not have a clear solution. The simulated modifications included enlarging the crosssectional area of the channel by increasing the distance between the levees upstream from the new bridge, installation of a relief structure in the cutoff channel, and removal of sediment from the new bridge opening. All modifications except the relief structure resulted in less than a 0.20 -foot decrease in upstream water elevations. The addition of a hypothetical relief structure that conveyed 10,20,30, or 40 percent of the Sanders Levee capacity (37,000 cubic feet per second) resulted in a $0.06-, 0.11-, 0.16-$, or 0.20 -foot decrease in upstream water-surface elevations, respectively.

\section{INTRODUCTION}

\section{Background}

The Kansas Department of Transportation (KDOT) realigned U.S. Highway 59 near Erie in southeast Kansas (fig. 1) in 1960. The old U.S. Highway 59 went through Erie and crossed the Neosho River just south of town. The new highway realignment bypassed Erie and required that a new bridge be built over the Neosho River southwest of Erie.

A bridge-site study was conducted by the U.S. Geological Survey (USGS) in 1960 (study on file with KDOT, Topeka, Kansas). This analysis determined that the new U.S. Highway 59 bridge and embankment would create only a $0.1-\mathrm{ft}$ increase in water-surface elevations on the upstream side of the bridge at river stages below $886 \mathrm{ft}$, which was the approximate elevation of nearby levees.

A Cook, Flatt \& Strobel Engineers report (1988) cited U.S. Army Corps of Engineers (USACE) watersurface elevations of 883 and $886 \mathrm{ft}$ at the new 


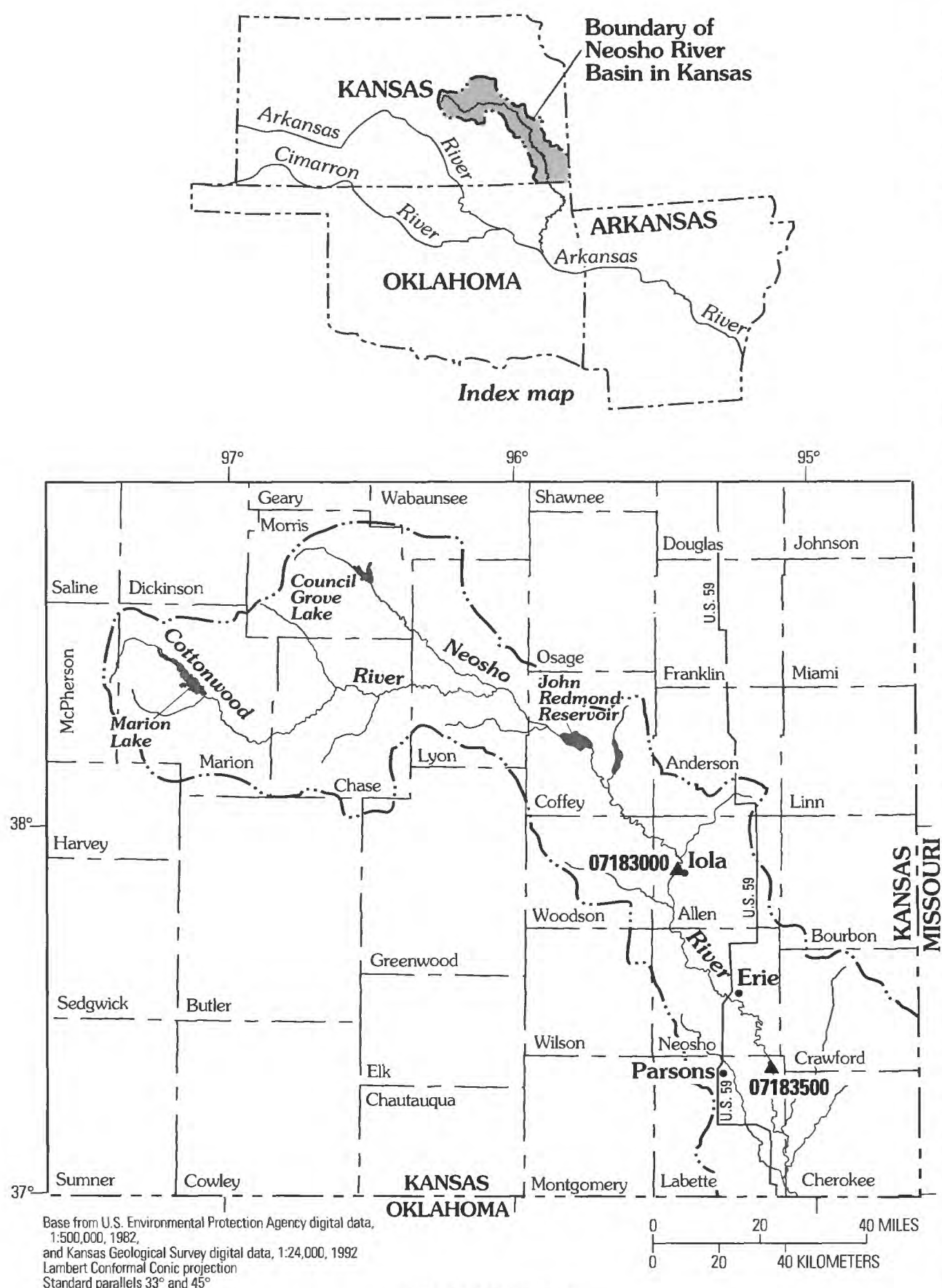

EXPLANATION

— - Boundary of Neosho River Basin

07183500 A U.S. Geological Survey streamflowgaging station and number
U.S. Highway 59 bridge for the Neosho River near Erie with discharges of 28,800 and $39,700 \mathrm{ft}^{3} / \mathrm{s}$, respectively. However, that analysis was not considered to meet KDOT standards.

Recent complaints by local residents of flooded property have focused attention to the U.S. Highway 59 crossing. Some residents believe this crossing is constricting the river during high flows, backing up water, and flooding property upstream from the U.S. Highway 59 crossing. An analysis of current (1999) flow conditions and water-surface elevations for increasingly larger discharges of the Neosho River near the new U.S. Highway 59 crossing at Erie was needed. This analysis would incorporate changes in the channel and hydraulic structures that have occurred since the 1960 analysis. Results of the analysis will add valuable knowledge as to how the crossing affects water-surface elevations at high flows and if indeed it is constricting. These results will provide the local residents and KDOT with a detailed explanation of the situation. Also, results will add valuable knowledge as to how different types of hydraulic structures affect the flow 
characteristics of similar streams in Kansas and across the Nation.

The U.S. Geological Survey, in cooperation with the Kansas Department of Transportation, conducted a study to perform an analysis of current (1999) flow conditions and water-surface elevations for large discharges of the Neosho River near the new U.S. Highway 59 crossing at Erie, Kansas, to update the 1960 bridge-site study.

\section{Purpose and Scope}

The purpose of this report is to describe an updated analysis of hydraulic (flow) conditions upstream and downstream from the U.S. Highway 59 crossing of the Neosho River at Erie, Kansas, and to present the water-surface elevations for cross sections upstream and downstream from the highway. Flow conditions in the Neosho River for annual peak discharges in 1986 and 1998 were simulated as well as the discharge at which water-surface elevations exceed the elevations of nearby levees. This report describes existing hydrologic data, the collection of additional hydrologic data, development of a hydraulic flow model, and use of the model to investigate current (1999) conditions and various modifications to hydraulic structures in the vicinity of the U.S. Highway 59 crossing of the Neosho River Valley to determine the effects on water-surface elevations upstream from the crossing.

\section{DESCRIPTION OF STUDY AREA}

The Neosho River Basin is located in southeastern Kansas (fig. 1). The flood plain of the Neosho River near Erie, Kansas (the study area), varies from 1.5 to 3 mi wide, is fairly straight, and is oriented northwest to southeast (fig. 2). The average slope of the river valley is about $1.5 \mathrm{ft} / \mathrm{mi}$ (Kansas Water Resources Board, 1961). The main channel of the Neosho River near Erie is well defined and incised into the valley floor, with maximum depths that average about $35 \mathrm{ft}$. Streamflow in the main channel of the Neosho River is perennial and has a mean annual discharge of about $2,700 \mathrm{ft}^{3} / \mathrm{s}$ (Putnam and others, 1999). The streambed in the vicinity of Erie is primarily clayey silt. Sections of the main channel have a fairly high sinuosity, and there is a lengthy, partially filled cutoff channel southwest of Erie (fig. 2).
Vegetation in the flood plain consists of various crops and grasses, with fairly dense stands of trees along the banks of the river, along ditches, and at the edges of agricultural fields. Levees have been constructed to protect agricultural fields from flooding on both sides of the main channel and can create a significant constriction to the flood plain during high flows. The city of Erie is mostly northeast of the flood plain on higher ground. However, several dwellings and agricultural fields are located within the flood plain.

\section{Hydrology}

The Neosho River at Erie, Kansas, has a drainage area of approximately $4,515 \mathrm{mi}^{2}$. Floodflows have been regulated since 1963 with the completion of John Redmond Reservoir located approximately $96 \mathrm{mi}$ (fig. 1) upstream. John Redmond Reservoir controls $3,015 \mathrm{mi}^{2}$ (or 67 percent) of the Neosho River Basin at Erie. Marion Lake and Council Grove Lake are upstream from John Redmond Reservoir (fig. 1) and control 200 and $240 \mathrm{mi}^{2}$, respectively, of the Neosho River Basin. The magnitude of flood peaks are reduced downstream from John Redmond Reservoir and are controlled by the U.S. Army Corp of Engineers, Tulsa, Oklahoma District.

The nearest streamflow-gaging stations to Erie on the river are the Neosho River near Iola and Neosho River near Parsons (USGS stations 07183000 and 07183500 , fig. 1), approximately 39 river mi upstream and 44 river mi downstream from Erie, respectively. The peak discharges at these locations since the closure of John Redmond Reservoir were $64,100 \mathrm{ft}^{3} / \mathrm{s}$ at station 07183000 on October 3, 1986, and $92,700 \mathrm{ft}^{3} / \mathrm{s}$ at station 07183500 on October 5, 1986 (Geiger and others, 1988). In the 25-year period from 1948 to 1973 , only three annual peak discharges recorded at the USGS streamflow-gaging station Neosho River near Parsons (station 07183500, 9 percent larger drainage area of the Neosho River than at Erie) were greater than $35,000 \mathrm{ft}^{3} / \mathrm{s}$ (data on file with USGS, Lawrence, Kansas). In the 25-year period from 1974 to 1999. there were 11 annual peak discharges at that station greater than $35,000 \mathrm{ft}^{3} / \mathrm{s}$ (data on file with USGS, Lawrence, Kansas).

The flood-frequency discharges for the Neosho River near Erie used in the analysis of the Dutton Levee system in 1988 (Cook, Flatt \& Strobel Engineers. 1988), which includes the effects of John Redmond Reservoir, were $28,800 \mathrm{ft}^{3} / \mathrm{s}$ for the 2 -year flood. 


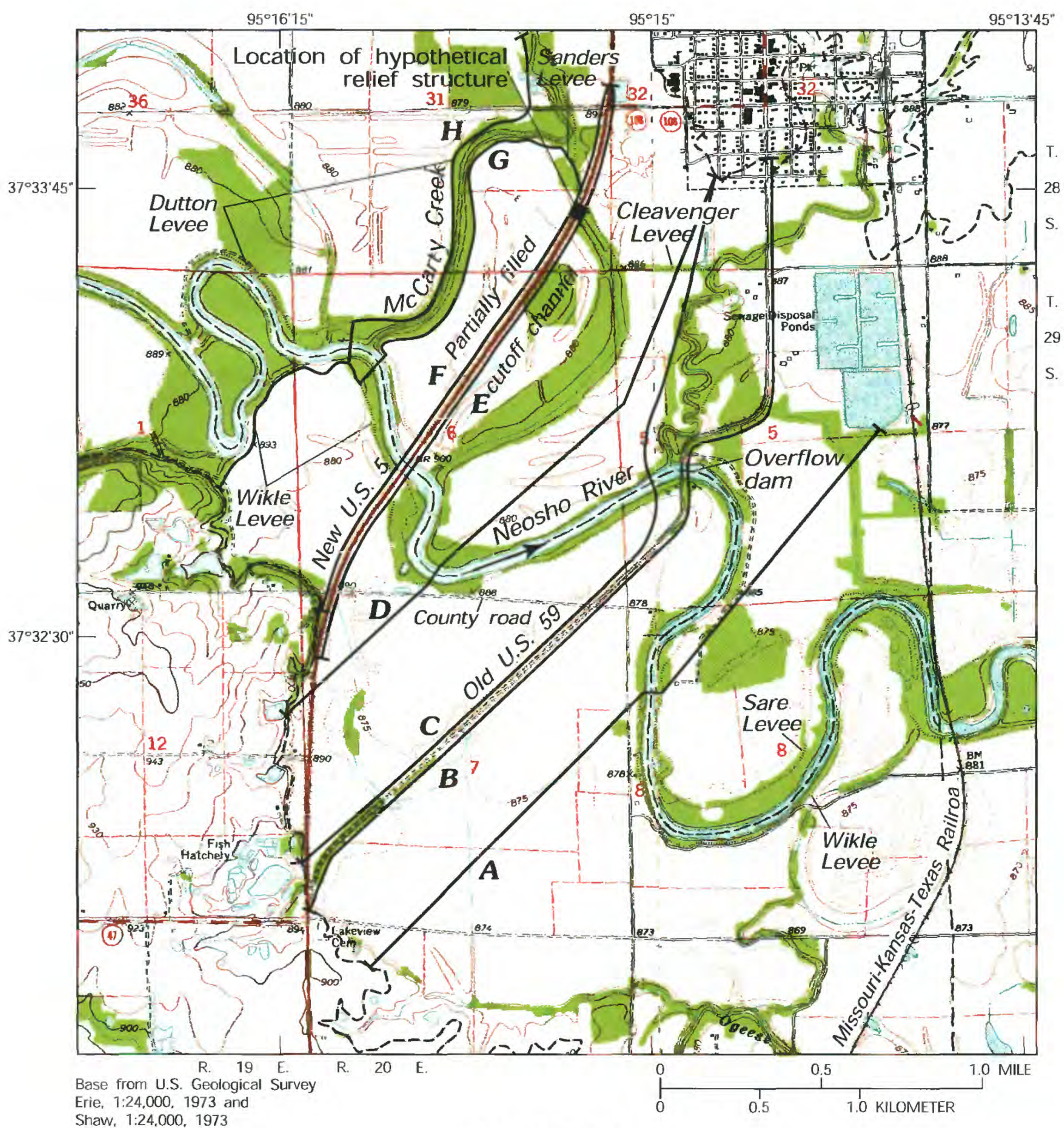

EXPLANATION

\section{$\stackrel{A}{\longmapsto}$ Trace of surveyed cross section and cross-section name}

8so- Topographic contour-Shows elevation of land surface. Contour interval 10 feet. Datum is sea level

\section{- - - Boundary of flood plain}

Corporate limits of Erie, Kansas

Levee

\section{Direction of flow}

8 Section number

Figure 2. Location of surveyed cross sections along Neosho River in vicinity of Erie, Kansas. 
$39,700 \mathrm{ft}^{3} / \mathrm{s}$ for the 5 -year flood, and $47,800 \mathrm{ft}^{3} / \mathrm{s}$ for the 10-year flood. The 50-year flood for the Neosho

River near Erie was determined by the USGS in 1960 to be $111,000 \mathrm{ft}^{3} / \mathrm{s}$, and the 100-year flood determined by the Federal Emergency Management Agency (1993) was $144,000 \mathrm{ft}^{3} / \mathrm{s}$.

McCarty Creek drains about $6.5 \mathrm{mi}^{2}$ of agricultural land north and west of Erie. The creek flows into the Neosho River about 2,000 ft upstream from U.S. Highway 59 between the Dutton and the Sanders Levees through the old cutoff channel of the Neosho River (fig. 2).

\section{Hydraulic Structures}

The reach of the Neosho River in the vicinity of Erie used for hydraulic analysis is complicated by several factors, including a railroad crossing, an overflow dam, two highway crossings (old and new U.S. Highway 59), and several levees on both sides of the river (fig. 2). These structures affect the backwater characteristics of the Neosho River and its tributaries in various ways that depend upon the magnitude of stream discharge.

The railroad crossing is located in the extreme eastern (downstream) reach of the river used for the analysis described in this report. The MissouriKansas-Texas Railroad (MKTRR) bridge had a hydraulic analysis conducted in 1986 by the Union Pacific Railroad Engineering Department (written commun., 1999).

Approximately 3 river mi upstream from the MKTRR bridge, an overflow dam (fig. $3 A$ ) creates an approximate 15-ft increase in the streambed elevation. Just upstream from the overflow dam ( $75 \mathrm{ft}$ ) is the old U.S. Highway 59 bridge, which was built in 1931 (fig. $3 B$ ). It is a steel-truss structure with three major spans. A slightly raised roadway embankment extends northward toward the city of Erie. To the south, parts of the old U.S. Highway 59 roadway embankment have been removed.

The new U.S. Highway 59 bridge (fig. $3 C$ ) is located 1.2 river mi upstream from the old bridge and is a five-span, steel-girder and concrete bridge. This bridge was constructed in 1960 along with an elevated roadway embankment that spans the entire valley.

Nearly all of both banks of the Neosho River in the vicinity of Erie, Kansas, have had levee construction. On the right bank (south), the Wikle Levee extends from the MKTRR bridge to upstream from the new U.S. Highway 59 bridge where it ties into high ground near the edge of flood plain in the SE 1/4 of sec. 1, T. 29 S., R. 19 E. (fig. 2). The Wikle Levee, built to its present height in 1948, is in close proximity to the south bank of the Neosho River channel all along its length.

On the left bank (north), the Sare Levee extends from the MKTRR bridge to just across the old U.S. Highway 59 embankment, then northward along the west side of old U.S. Highway 59 to where it ties into the old U.S. Highway 59 embankment south of Erie (fig. 2). The Sare Levee was brought to its present height in 1943. A private levee $5,000 \mathrm{ft}$ north of the river, currently owned by Ernest Cleavenger, ties in with the new U.S. Highway 59 embankment. This private levee continued northward ending on high ground west of the city of Erie (fig. 2) before construction of the new U.S. Highway 59. The next levee upstream, north of the river, is the Sanders Levee, which extends from the new U.S. Highway 59 bridge embankment upstream along the Neosho River and then turns northeastward along McCarty Creek until it ties back into the new U.S. Highway 59 embankment (fig. 2). The Sanders Levee was built in 1971 as an improvement to an older private levee, and connects with the Cleavenger Levee at its northeast end. A short section of the original Cleavenger Levee was removed, which allows water from McCarty Creek to back up to the new U.S. Highway 59 embankment.

The Dutton Levee extends along the west bank of McCarty Creek from the Atchison Topeka and Santa Fe Railway (AT\&SFR) (located about $0.5 \mathrm{mi}$ north of the area shown in figure 2) in NE 1/4 of sec. 25, T. 28 S., R. 19 E., to the confluence of McCarty Creek and the Neosho River and then westward along the Neosho River to the mouth of Canville Creek (located approximately $3 \mathrm{mi}$ west of Erie and flows from north to south into the Neosho River, not shown in figure 2) and then back north to the AT\&SFR in sec. 23, T. 28 S., R. $19 \mathrm{E}$.

\section{Existing Alignment and Features of U.S. Highway 59}

The section of U.S. Highway 59 that crosses the flood plain of the Neosho River is about $4 \mathrm{mi}$ in length. The roadway is a 28 - $\mathrm{ft}$-wide asphalt pavement with approximately 8 -ft-wide gravel shoulders. The height 


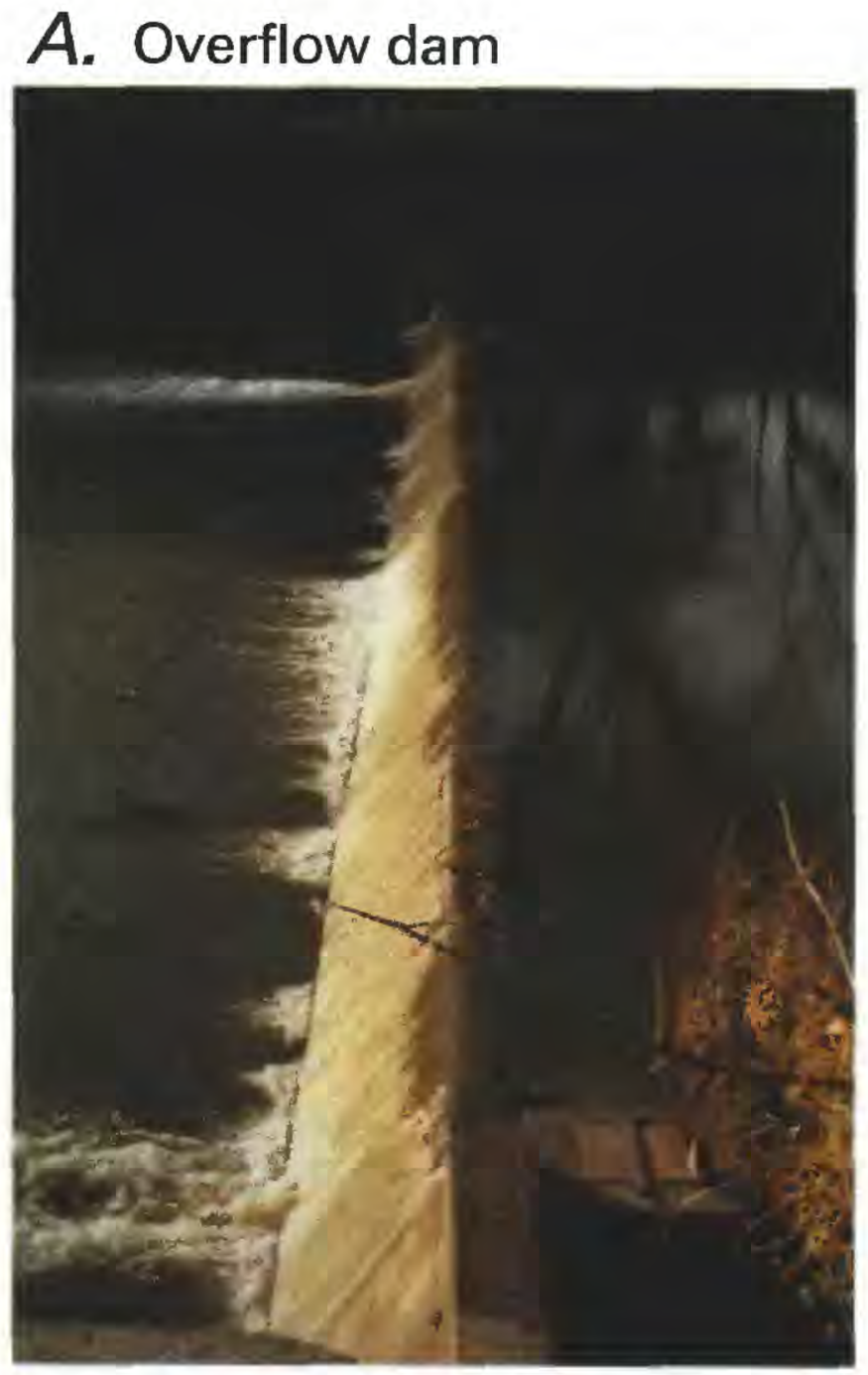

B. Old U.S. Highway 59 bridge

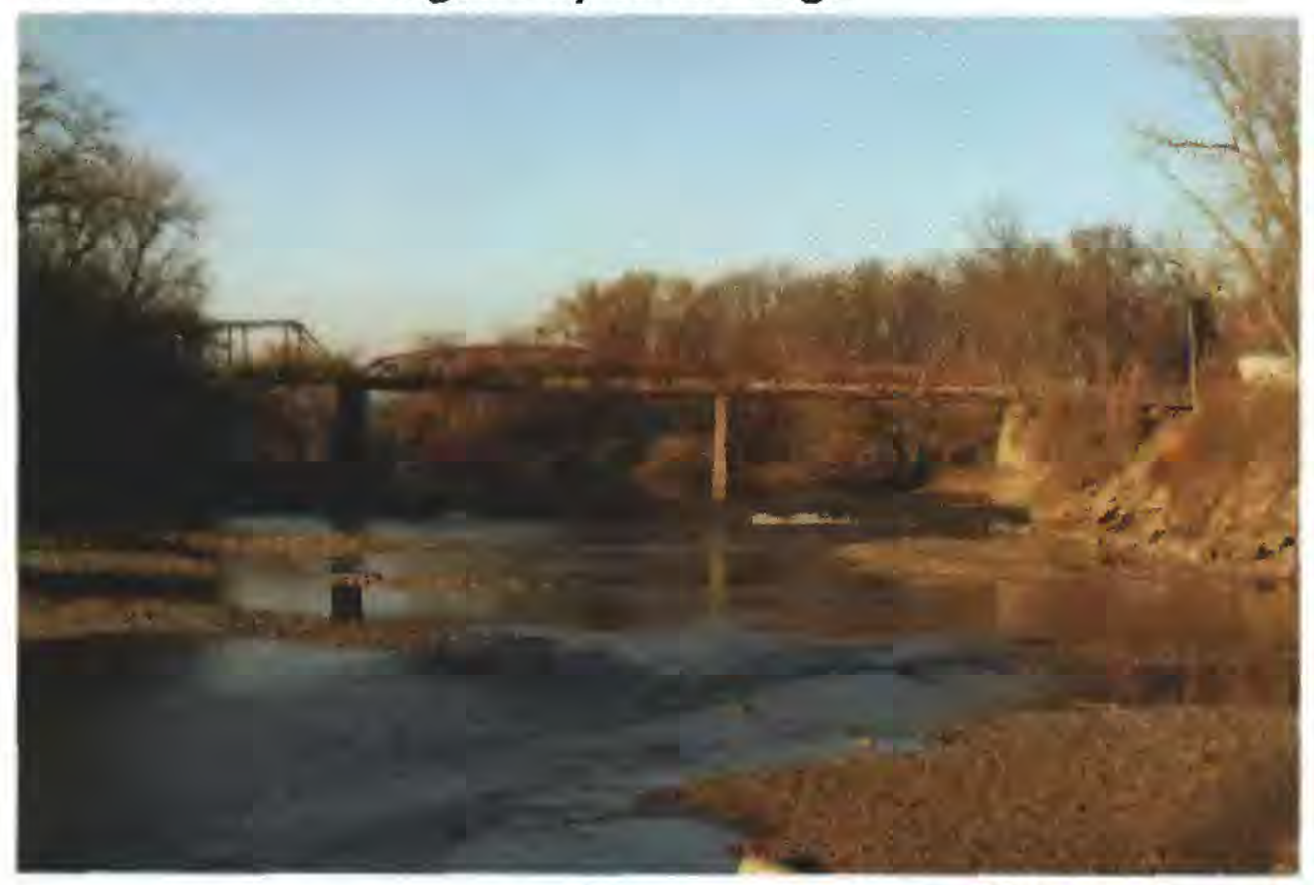

Photograph taken looking upstream.

\section{New U.S. Highway 59 bridge}

Photograph taken from left bank.

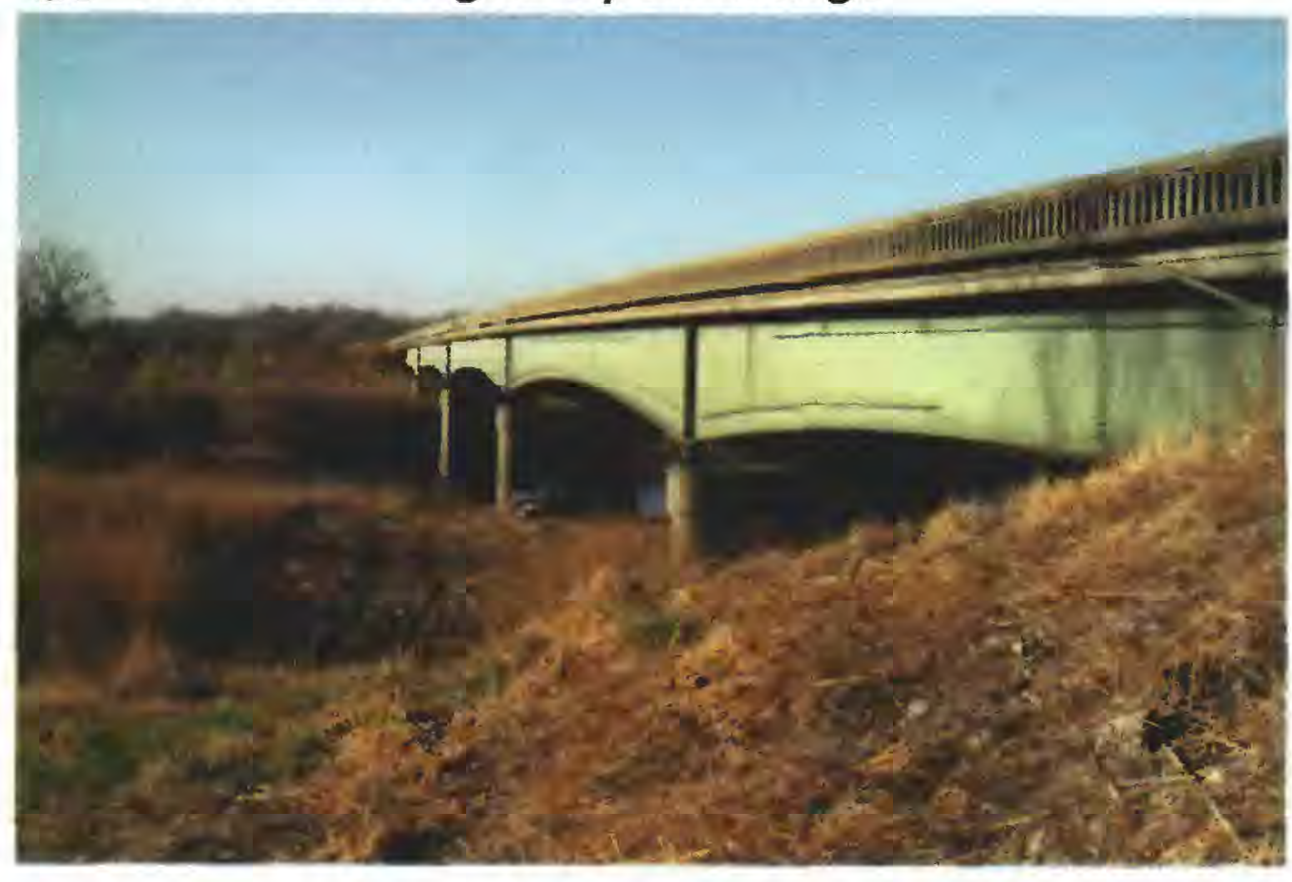

Photograph taken from left bank.

Figure 3. (A) Overflow dam just downstream from old U.S. Highway 59 bridge, (B) old U.S. Highway 59 bridge, and (C) new U.S. Highway 59 bridge at Erie, Kansas.

of the roadway embankment varies from approximately 10 to $15 \mathrm{ft}$ above the flood plain. Elevation of the north end of the roadway gently decreases as the road approaches the main channel. The elevation of the roadway then increases to the bridge deck over the main channel and is about $20 \mathrm{ft}$ above the flood plain. The south roadway embankment extends from the new bridge to the edge of flood plain. The lowest elevation of the roadway $(890.0 \mathrm{ft}$ ) is about $2,000 \mathrm{ft}$ south of the bridge near the intersection with an east-west gravel road.
The north roadway embankment crosses an old sediment-filled cutoff channel (partially filled cutoff channel, figure 2) of the Neosho River. During construction, this channel was completely filled beneath the roadway, and local drainage from McCarty Creek was routed to the west part of the old cutoff channel. This channel was graded to allow drainage to the Neosho River.

The primary drainage structure under the U.S. Highway 59 roadway is a 830 -ft-long, steel-girder and concrete bridge supported by the two abutments and 


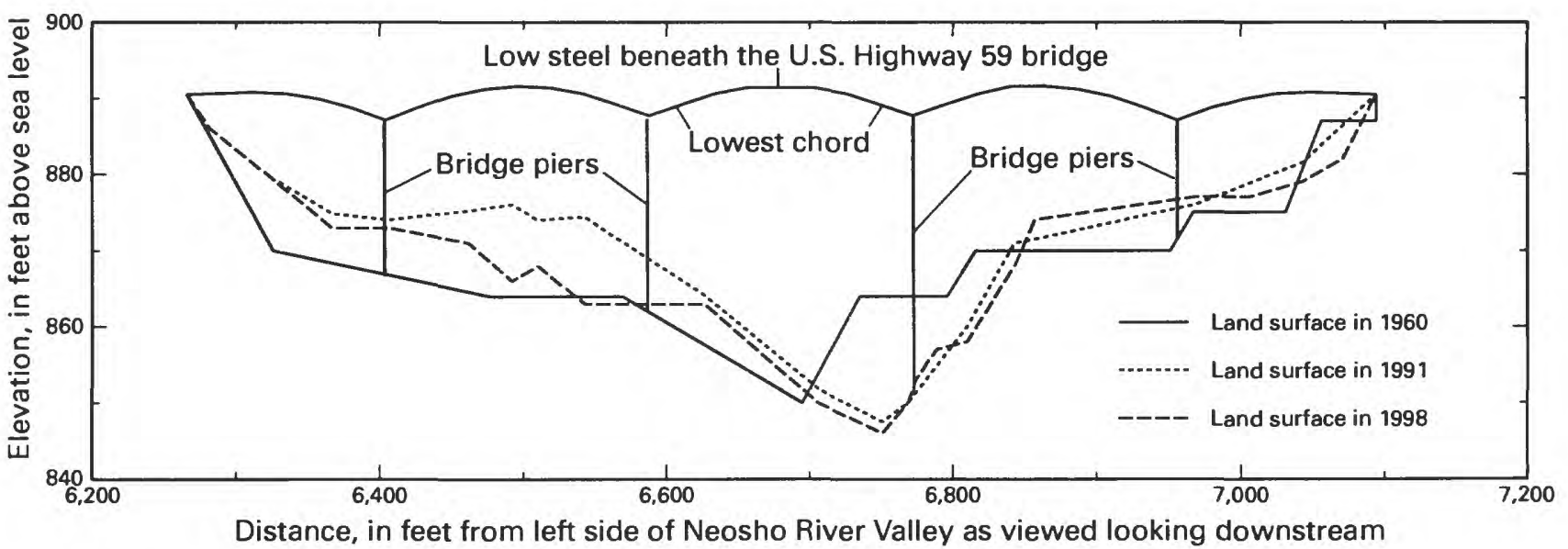

Figure 4. New U.S. Highway 59 bridge openings in 1960, 1991, and 1998.

four piers. The lowest chord (fig. 4) elevation of the bridge is $887.1 \mathrm{ft}$. The cross-sectional area of the bridge opening is approximately $17,000 \mathrm{ft}^{2}$. The center line of the river channel beneath the bridge has migrated southward approximately $60 \mathrm{ft}$ since the bridge was constructed, and the original crosssectional opening was reduced by deposition of sediment. This sediment was partially removed by KDOT in 1998, and the cross-sectional area under the bridge was increased. Currently (1999), some sediment deposition is reoccurring. Cross sections of the bridge opening in 1960, 1991, and 1998 (data are from KDOT plans and surveys on file in Topeka, Kansas) are shown in figure 4.

There are several culverts conveying water through the roadway embankment. One small, twobarrel, 5- x 5-ft box culvert carries local drainage through the roadway embankment south of the bridge. Two round 24-in. equalizer culverts were constructed through the embankment north of the main bridge. The total discharge through these culverts is negligible relative to the discharge through the main bridge opening.

\section{HYDRAULIC ANALYSIS}

\section{Cross Sections}

Cross-sectional data along the study reach were collected by USGS personnel in 1999. The data included channel cross sections; roadway profiles of new and old U.S. Highway 59; the geometric details of the new and old bridges, relief drainage structures, and overflow dam; and top-of-levee elevations. Bridge and culvert elevations either were surveyed or taken from original construction plans (on file with KDOT,

Topeka, Kansas). Channel roughness coefficients were estimated from onsite inspection of the channel, overflow sections, and drainage structures. Cross sections A through $\mathrm{H}$ are shown in figures 5-12 in downstream-to-upstream order. Each cross section consists of surveyed elevations within the main channel to the levees, and elevations from topographic maps from the levees to the edge of the flood plain. All of the cross sections are leveed on the south bank by the Wikle Levee. Each cross section is either leveed on the north by the Sare, Sanders, Cleavenger, or Dutton Levees. The cross sections are described in the following paragraph.

Cross section A (fig. 5) is located about $4,000 \mathrm{ft}$ downstream from the overflow dam and includes the Sare Levee on the left bank and the Wikle Levee on the right bank. Cross section B (fig. 6) is $75 \mathrm{ft}$ downstream from the old U.S. Highway 59 bridge and includes the overflow dam and the Sare and Wikle Levees. The old U.S. Highway 59 roadway embankment, including the main bridge opening, is shown with cross section $\mathrm{C}$ in figure 7 . The area of the main bridge opening is approximately $9,000 \mathrm{ft}^{2}$. Parts of the old U.S. Highway 59 embankment southwest of the main bridge have been removed. Cross section $\mathrm{C}$ and D (figs. 7 and 8) are leveed on the south by the Wikle Levee and about $5,000 \mathrm{ft}$ to the north by the Cleavenger Levee. Cross section $\mathrm{E}$, the section $800 \mathrm{ft}$ downstream from the new U.S. Highway 59 bridge, is leveed on the north by the Cleavenger Levee and is 


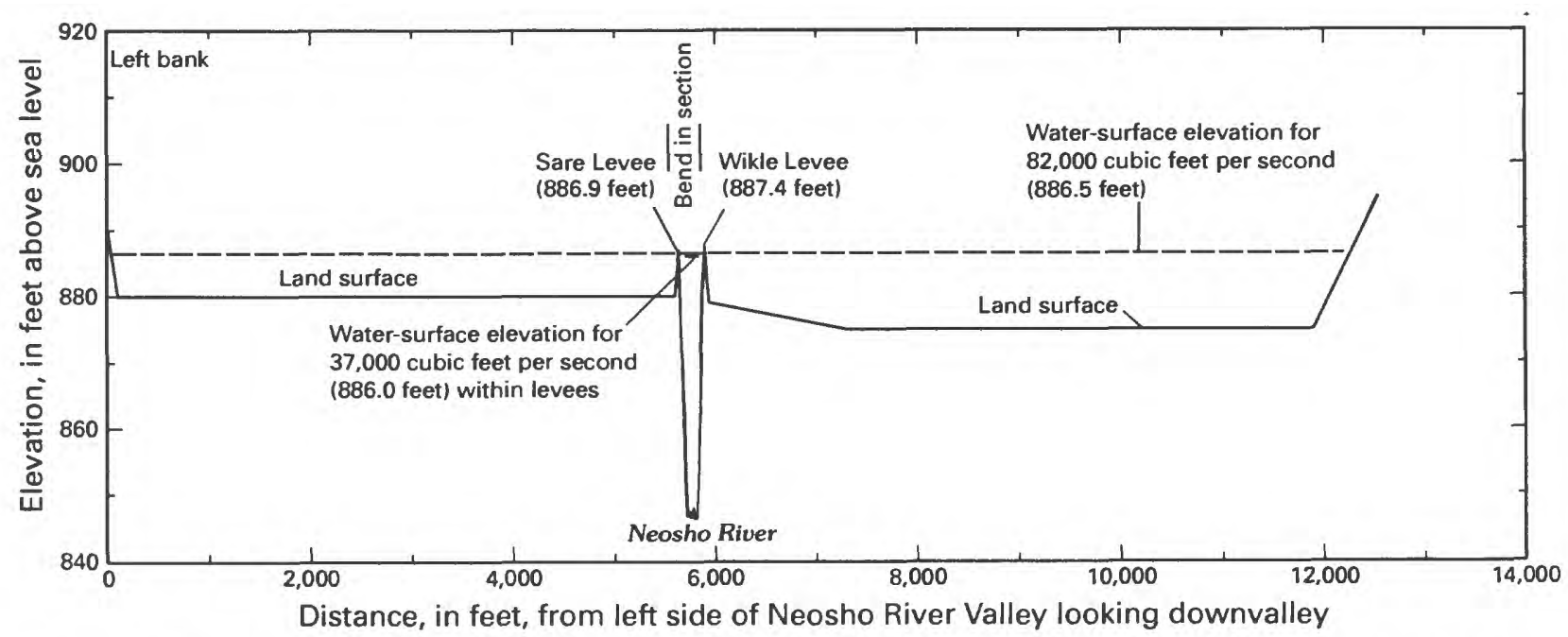

Figure 5. Cross section A across Neosho River near Erie, Kansas, 1999, with water-surface elevations for discharges of 37,000 and 82,000 cubic feet per second. Location of cross section shown in figure 2 .

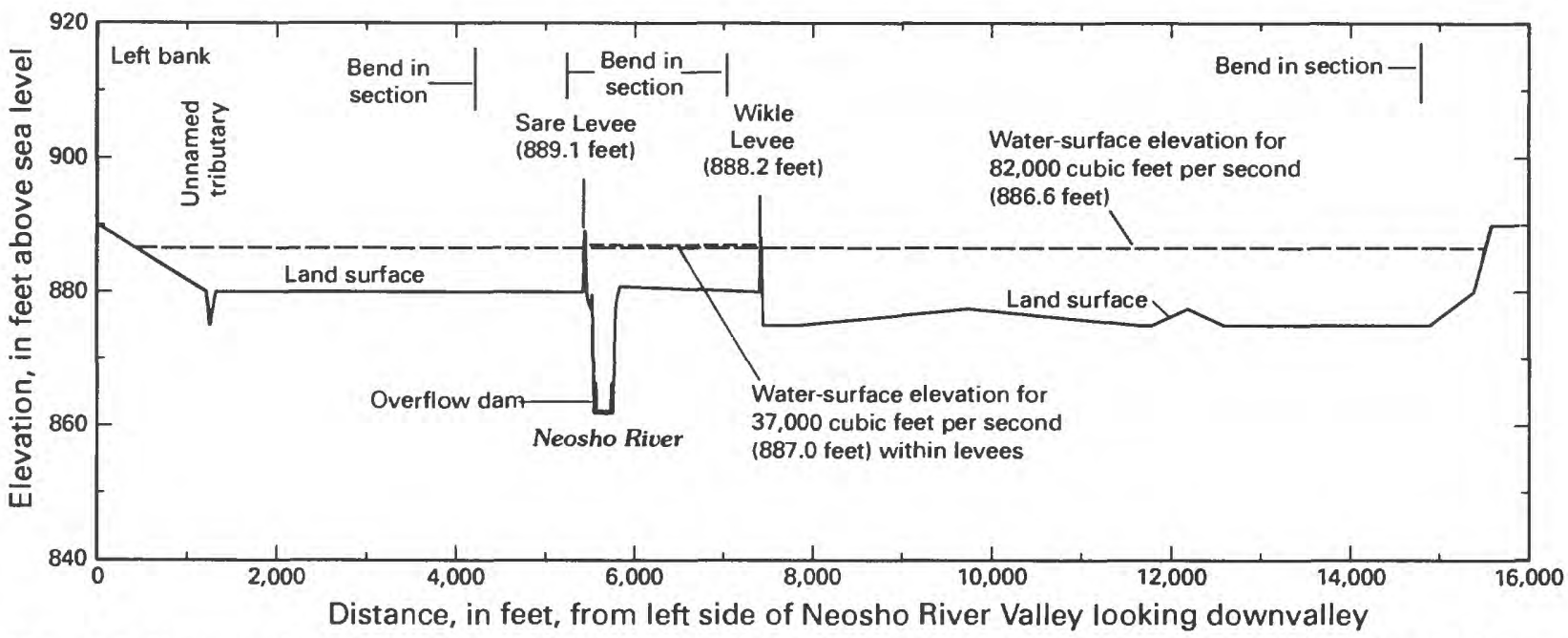

Figure 6. Cross section B across Neosho River near Erie, Kansas, 1999, with water-surface elevations for discharges of 37,000 and 82,000 cubic feet per second. Location of cross section shown in figure 2 .

leveed on the south by the Wikle Levee (fig. 9). The section upstream from the new U.S. Highway bridge shown in cross section F (fig. 10) is leveed on both sides by the Sanders and Wikle Levees. Cross section G (fig. 11) follows the Sanders Levee from the new U.S. Highway 59 embankment west and south to the river, crosses the main channel of the Neosho River, then follows along the Wikle Levee to coincide with cross section $\mathrm{H}$ to the edge of the flood plain. Cross section $\mathrm{H}$ (fig. 12) follows the Dutton Levee, crosses the Neosho River, then follows along the Wikle Levee southwest to the edge of flood plain. Both cross sections $\mathrm{G}$ and $\mathrm{H}$ include levees that effectively cross the valley at right angles, and are impediments to the higher discharges that require the full valley width.

\section{Hydraulic Flow Model}

The hydraulic flow model used in this analysis is WSPRO (Water Surface Profile) (Shearman, 1990). The WSPRO model was developed by the USGS in cooperation with the U.S. Department of Transportation, Federal Highway Administration. It is a stepbackwater model that integrates computation routines to define the flow through a bridge opening (Matthai, 


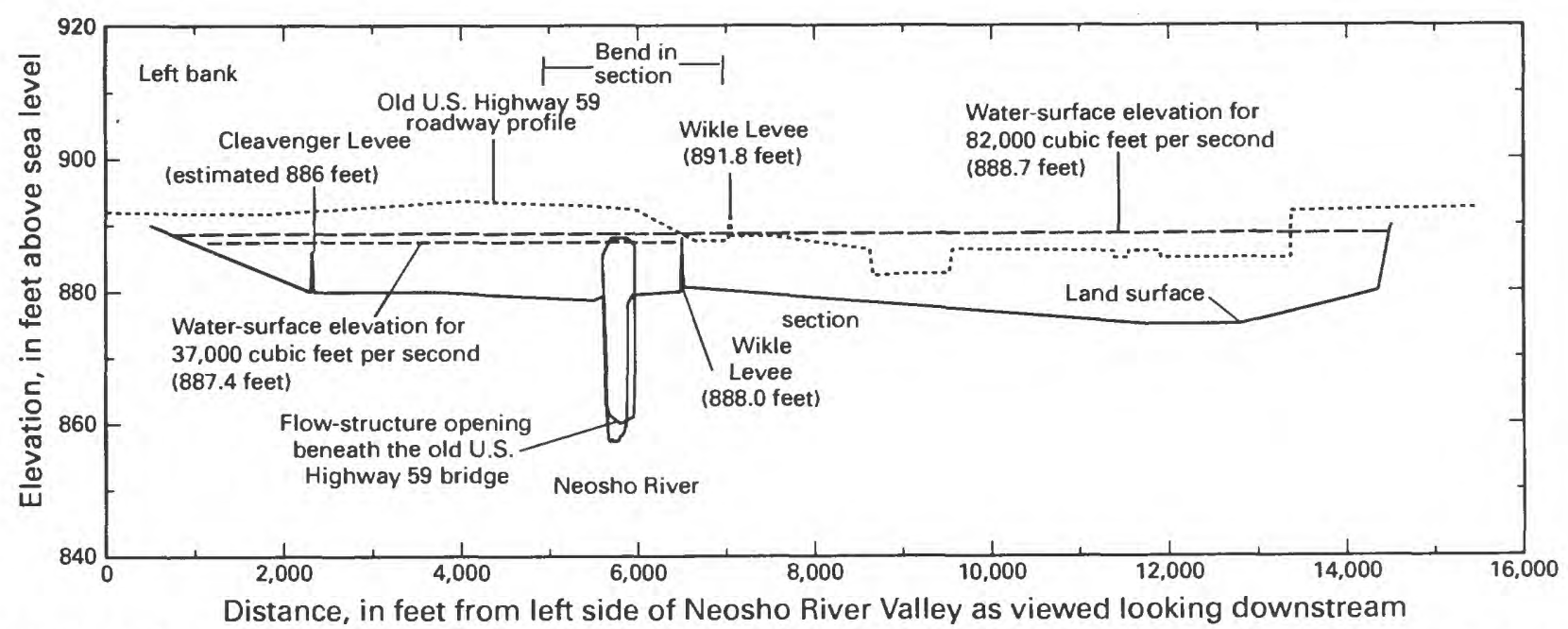

Figure 7. Cross section C and old U.S. Highway 59 roadway profile across Neosho River near Erie, Kansas, 1999, and flow-structure opening with water-surface elevations for discharges of 37,000 and 82,000 cubic feet per second. Location of cross section shown in figure 2.

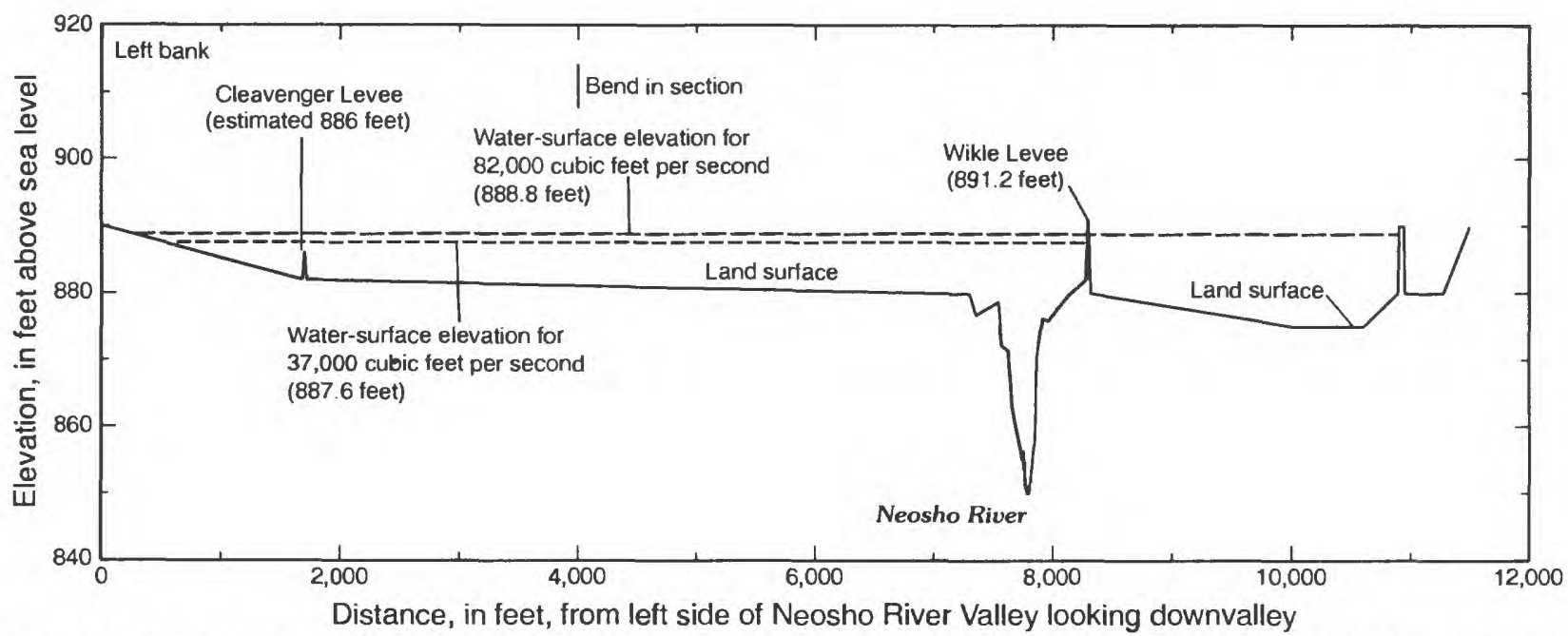

Figure 8. Cross section D across Neosho River near Erie, Kansas, 1999, with water-surface elevations for discharges of 37,000 and 82,000 cubic feet per second. Location of cross section shown in figure 2 .

$1967)$ and flow over roadways. It uses onedimensional, gradually varied, steady-state conditions to estimate water-surface elevations in open channels (Davidian, 1984). The model is flexible and can be used to analyze different flow discharges as well as various drainage and roadway geometries.

The WSPRO analysis of the Neosho River in the vicinity of the new U.S. Highway 59 bridge was conducted in several phases. The first phase was to determine the maximum flow of the Neosho River that could be contained by the levees. Elevations obtained by this WSPRO analysis could be verified by discharge and water-surface elevation measurements made from the flood of November 1998. This analysis is described in the following section, "Flows Within Levees." Floodwater leaves the main channel and spills onto the valley floor at the point where the lowest levee is overtopped. This transition phase cannot be adequately simulated as flow is no longer in a steadystate condition and, therefore, does not meet that assumption of the WSPRO model. The next phase was to model the river after the leveed areas of the flood plain have filled with floodwater. At this point the river returns to a steady-state flow regime, and flood elevations again can be determined adequately from flood discharges using the WSPRO model. Elevations 


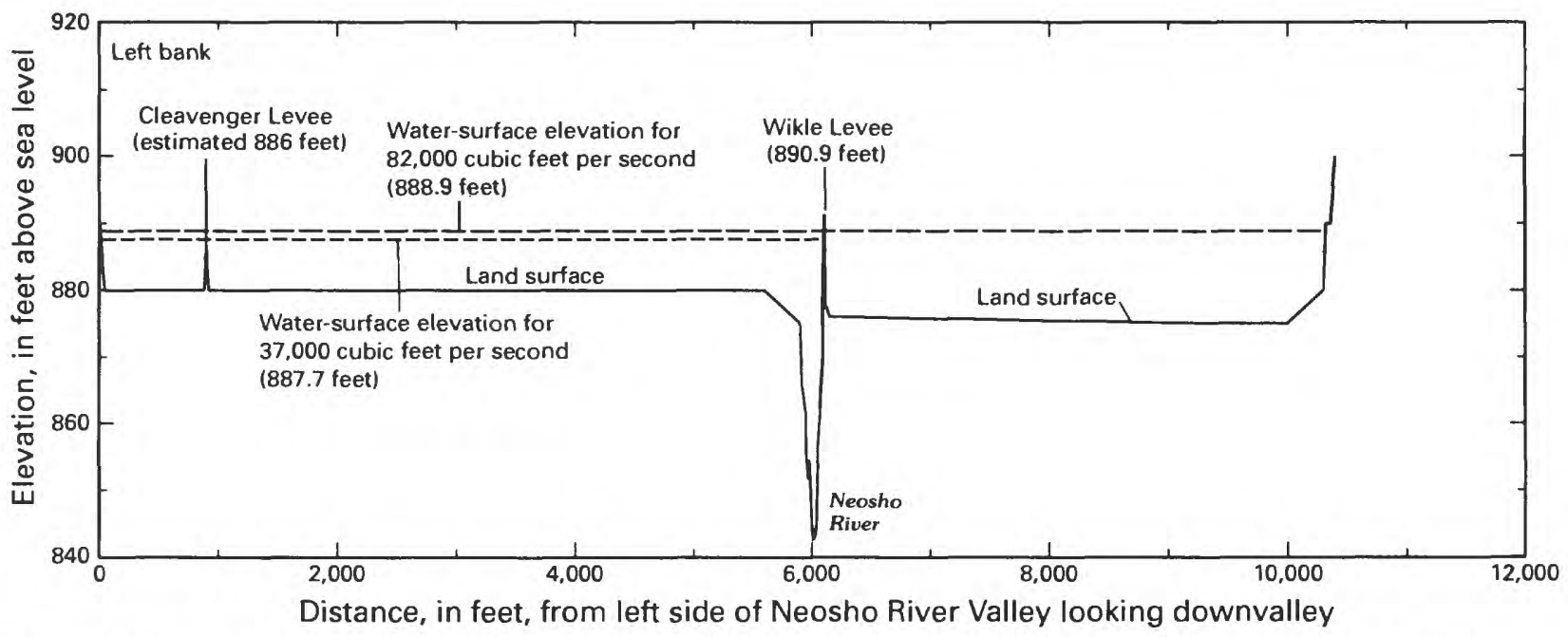

Figure 9. Cross section E across Neosho River near Erie, Kansas, 1999, with water-surface elevations for discharges of 37,000 and 82,000 cubic feet per second. Location of cross section shown in figure 2 .

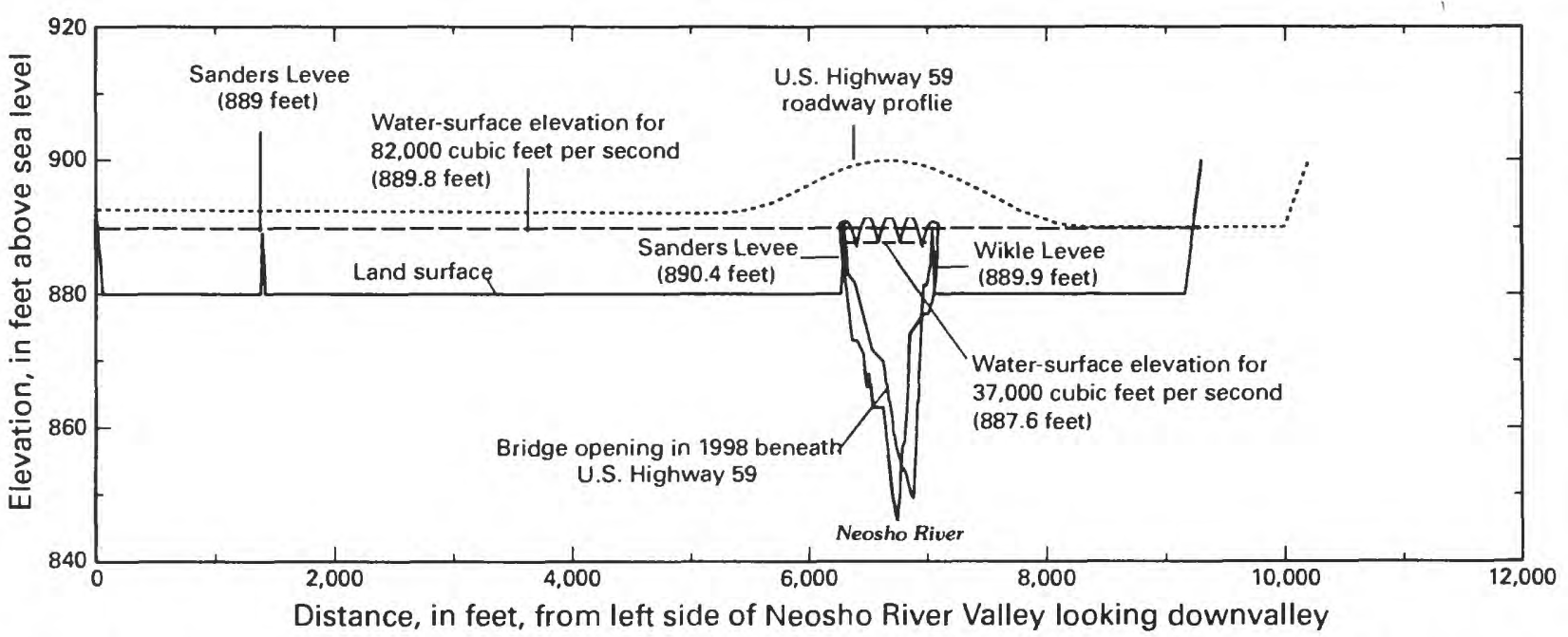

Figure 10. Cross section F and new U.S. Highway 59 roadway profile across Neosho River near Erie, Kansas, 1999 , and flow-structure opening with water-surface elevations for discharges of 37,000 and 82,000 cubic feet per second. Location of cross section in figure 2.

obtained by this WSPRO analysis could be verified by discharge and water-surface elevation measurements made for the flood of October 1986. This analysis is described in the following section, "Flows Within Flood Plain." Other phases included WSPRO analyses of various discharges through a hypothetical relief structure in the new U.S. Highway 59 embankment on the north side of the river (fig. 2) as well as hypothetical modifications to Sanders Levee upstream from the new U.S Highway 59 bridge. These analyses are described in the following section, "Flows Within Channel, Bridge Opening, and Levee Changes."

\section{Flows Within Levees}

The WSPRO program was applied using discharges from 33,000 to $39,000 \mathrm{ft}^{3} / \mathrm{s}$ to determine the flow at which the levees are first overtopped in the vicinity of the new U.S. Highway 59 bridge using 1960, 1991, and 1998 bridge-opening data (fig. 4). Results using the 1960 data indicated an approximate 0.20 - $\mathrm{ft}$ increase in water levels through the new U.S. Highway 59 structure at each discharge with no significant backwater (fig. 13). The sediment that had been deposited under the bridge by 1991 produced an 


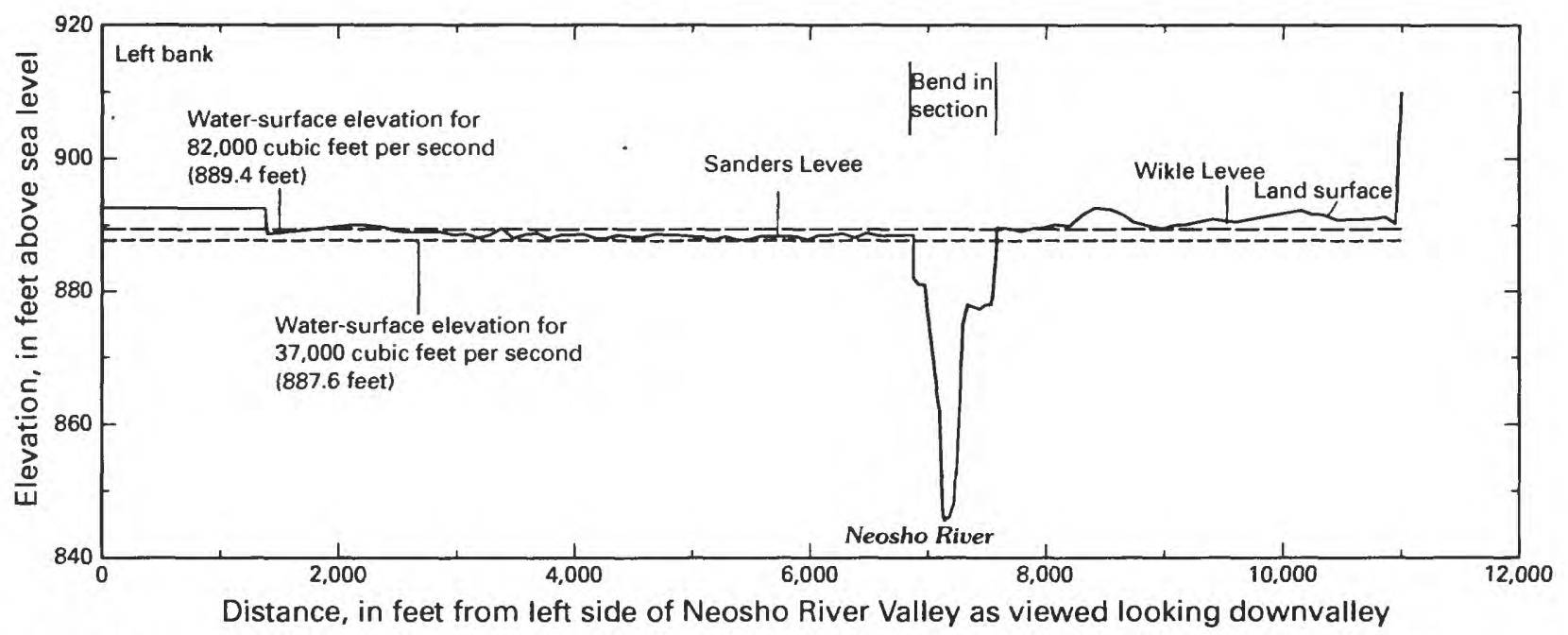

Figure 9. Cross section E across Neosho River near Erie, Kansas, 1999, with water-surface elevations for discharges of 37,000 and 82,000 cubic feet per second. Location of cross section shown in figure 2.

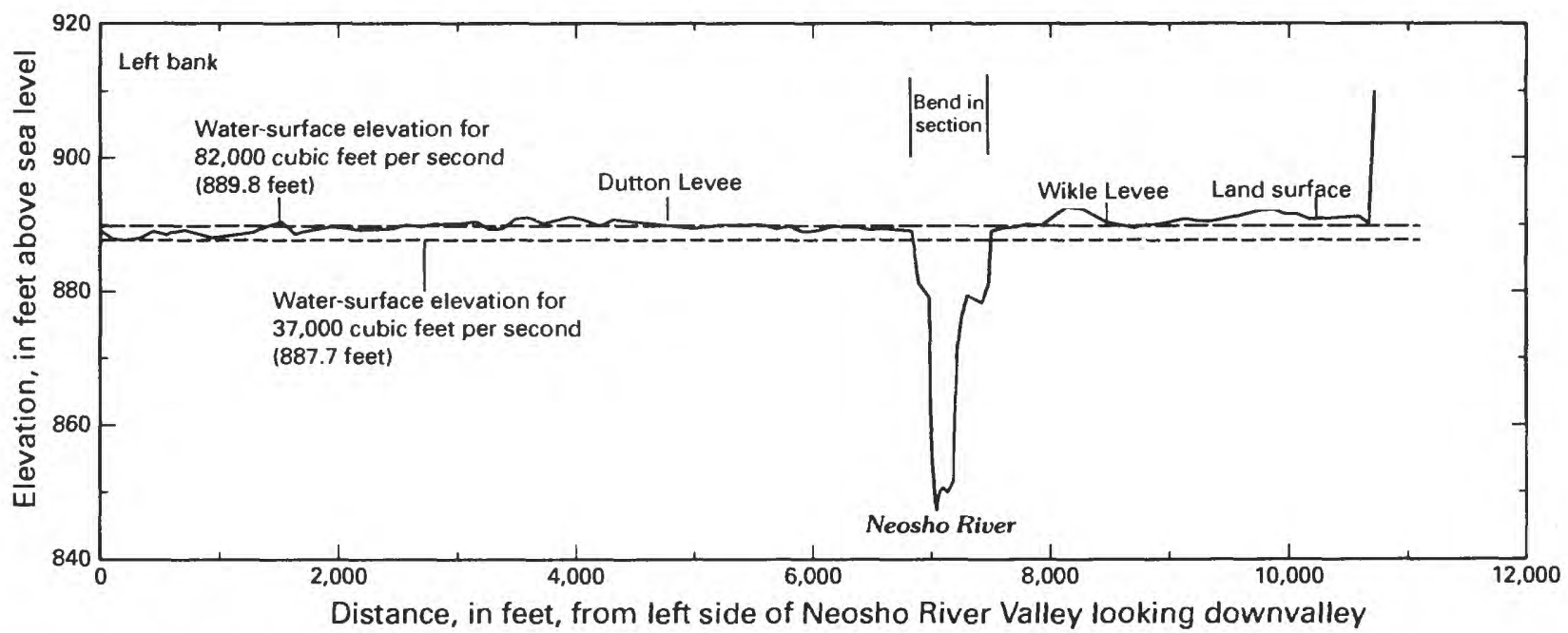

Figure 12. Cross section $\mathrm{H}$ across Neosho River near Erie, Kansas, 1999, with water-surface elevations for discharges of 37,000 and 82,000 cubic feet per second. Location of cross section shown in figure 2 .

overall increase in water elevations of approximately $0.20 \mathrm{ft}$ at each discharge compared to the water elevations related to the 1960 opening.

The WSPRO analysis using current (1999) crosssection data and a discharge of $37,000 \mathrm{ft}^{3} / \mathrm{s}$ indicated that the water-surface elevation under the new U.S. Highway 59 bridge is $887.6 \mathrm{ft}$. This elevation coincides with the high-water mark under the new U.S. Highway 59 bridge surveyed at an elevation of $887.63 \mathrm{ft}$ at a discharge of $37,000 \mathrm{ft}^{3} / \mathrm{s}$ in November 1998. Further WSPRO analysis indicates that the Sanders Levee is overtopped at cross section $\mathrm{H}$ as the discharge exceeds $37,000 \mathrm{ft}^{3} / \mathrm{s}$ and the water-surface elevation exceeds $887.7 \mathrm{ft}$ (fig. 12). On the south side of the river at cross section $\mathrm{G}$, the Wikle Levee is overtopped at a discharge of about $37,000 \mathrm{ft}^{3} / \mathrm{s}$ when the water-surface elevation exceeds $887.8 \mathrm{ft}$. At this discharge, water from the Neosho River is going into storage behind the Sanders Levee.

According to model simulations of water-surface elevations, levee overtopping initially occurs upstream from the U.S. Highway 59 crossing (fig. 13). Levees downstream from the U.S. Highway 59 embankment are overtopped as the water-surface elevation at cross section $\mathrm{C}$ exceeds $888.0 \mathrm{ft}$ (discharge above $38,000 \mathrm{ft}^{3} / \mathrm{s}$ ). 


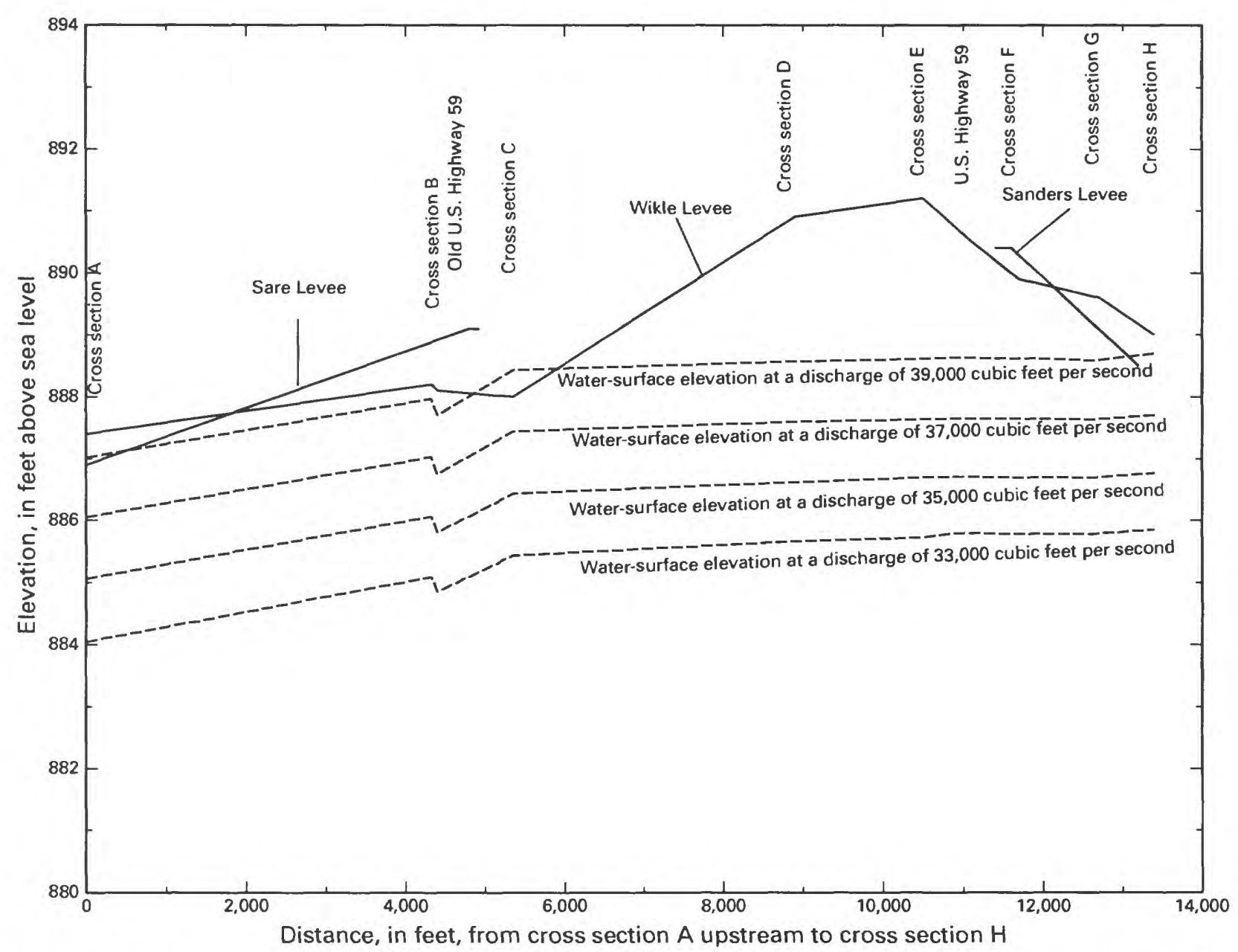

Figure 13. Simulated water-surface elevations using 1960 bridge-opening data for Neosho River near Erie, Kansas, for various flood discharges within levees.

\section{Flows Within Flood Plain}

Most of the cross sections used in the full-valley model included elevations from the flood plain outside the levees. The exceptions were cross sections $\mathrm{G}$ and H just upstream from the new U.S. Highway 59 bridge where McCarty Creek enters the Neosho River. Downstream from this confluence, cross section $G$ includes the Sanders and Wikle Levees (fig. 2). These levees, along with a narrow main channel. combine to form a major constriction within the flood plain. Upstream from the Neosho River and McCarty Creek confluence, cross section $\mathrm{H}$ follows along the Dutton Levee just west of McCarty Creek, crosses the Neosho River upstream from the mouth of McCarty Creek. and then follows the Wikle Levee to the south edge of flood plain. The cross-sectional area for cross section $\mathrm{H}$ is not as constrictive as that for cross section $\mathrm{G}$ (figs. 11 and 12).
As the river discharge increases above $38,000 \mathrm{ft}^{3} / \mathrm{s}$, the water-surface elevation in the main channel increases only slightly as the flood plain begins to convey water downstream. This continues as the discharge increases until the water level in the flood plain matches the level in the main channel. At this level, flow approaches steady state and can be modeled adequately.

The flood of October 1986 filled the flood plain and provides another discharge-elevation verification of the model at the full valley level. The discharge of this flood was estimated to be approximately $82,000 \mathrm{ft}^{3} / \mathrm{s}$ at Erie (Putnam and others, 1999), and a well-preserved high-water mark under the new U.S. Highway 59 bridge indicates that the watersurface elevation under the bridge was $888.8 \mathrm{ft}$ (fig. 14). Model simulations of $82,000 \mathrm{ft}^{3} / \mathrm{s}$ also result in a flood elevation of $888.8 \mathrm{ft}$ at the U.S. Highway 59 bridge. 


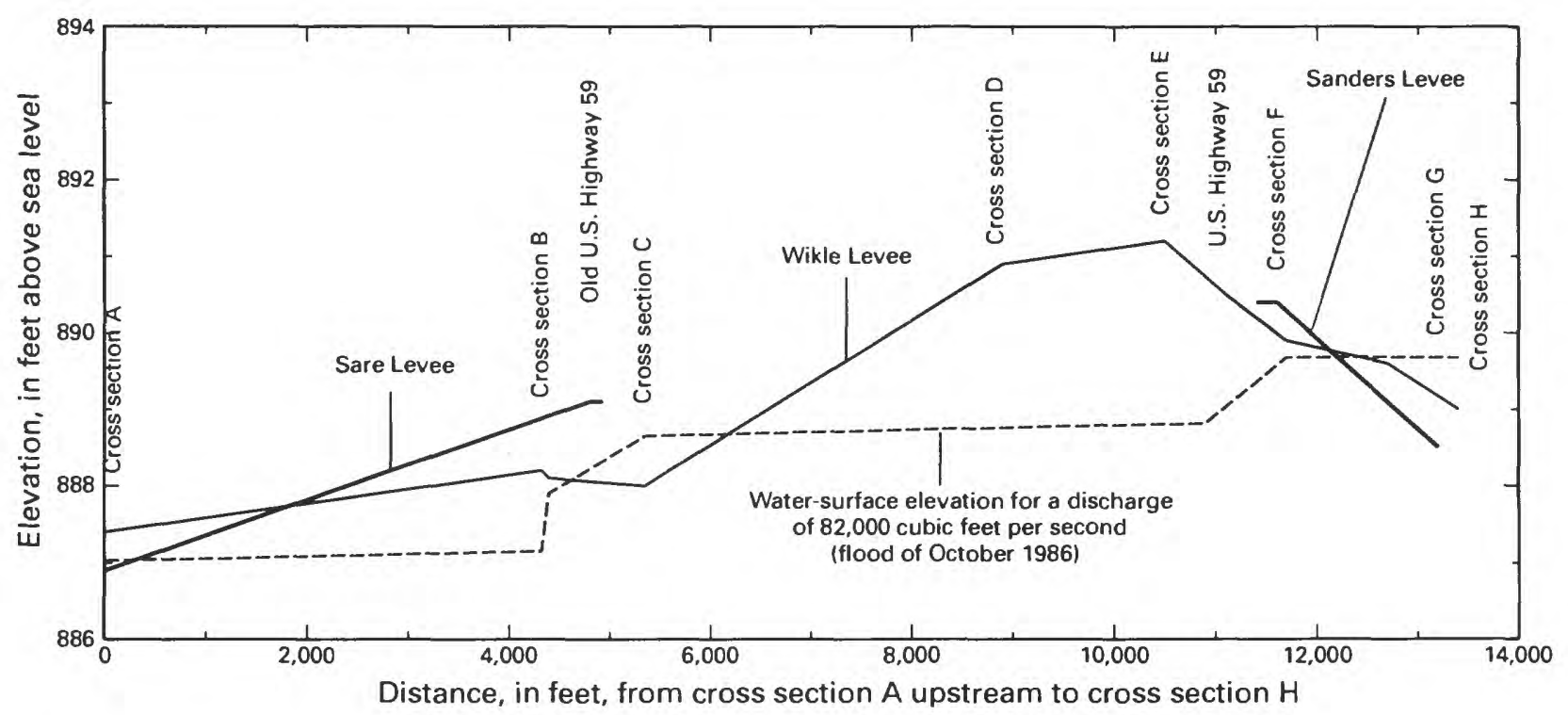

Figure 14. Simulated water-surface elevations for flood of October 1986 within flood plain, Neosho River near Erie, Kansas.

Simulated water-surface elevations indicate that the depth of the backwater from U.S. Highway 59 for $82,000 \mathrm{ft}^{3} / \mathrm{s}$ was approximately $1.0 \mathrm{ft}$. Water-surface elevations exceed levee elevations by as much as $0.6 \mathrm{ft}$ at a discharge of about $82,000 \mathrm{ft}^{3} / \mathrm{s}$. The model does not indicate any flow over the road just south of the intersection of the county road between secs. 1 and 12 , T. 29 S., R. 19 E. (fig. 2) as was observed during the October 1986 flood. This discrepancy could be explained by water-surface elevations exceeding the levee elevations at the western terminus of the Wikle Levee, allowing floodwaters to reach the U.S. Highway 59 embankment at levels slightly higher than the lowest elevation for the U.S. Highway 59 embankment $(890.0 \mathrm{ft})$. An additional model simulation using the estimated 50-year flood discharge, $111,000 \mathrm{ft}^{3} / \mathrm{s}$, indicated that the U.S. Highway 59 bridge and embankment created a backwater depth of $1.2 \mathrm{ft}$.

\section{Flows Within Channel, Bridge Opening, and Levee Changes}

Various hypothetical modifications to the hydraulic structures in the Neosho River Valley in the vicinity of the U.S. Highway 59 crossing were simulated using WSPRO. These simulated modifications included enlarging the cross-sectional area of the channel by increasing the distance between the levees upstream from the new bridge, installation of a relief structure in the cutoff channel, and removal of sediment from the new bridge opening. These model simulations indicate that the problem of levee overtopping upstream from the new U.S. Highway 59 bridge over the Neosho River does not have a clear solution. Modifications that resulted in decreasing conveyance were not considered because an increase in velocity (and bank/levee erosion) was not desirable.

One method of decreasing the water-surface elevations at cross section $\mathrm{H}$ would be to reduce the constriction at cross section $\mathrm{G}$ by increasing the distance between the levees. This was accomplished by simulating moving the Sanders Levee north $150 \mathrm{ft}$ and excavating the channel bank (fig. 15). This cross section is at the location where the cutoff channel was breached by the river. The banks are fairly high on both sides of the river, and the channel shows signs of widening as there is a steep cutbank on the left bank. The model simulation with this modification of cross section $\mathrm{G}$ indicates that, at a discharge of $37,000 \mathrm{ft}^{3} / \mathrm{s}$, the water-surface elevation at cross section $\mathrm{H}$ decreases $0.1 \mathrm{ft}$ (table 1).

A second method of decreasing water-surface elevations upstream from the new U.S. Highway 59 bridge is the addition of a hypothetical relief structure through the highway embankment in the vicinity of the old cutoff channel (sec. 31, T. 28 S., R. 20 E., figure 2). This concept was simulated using a discharge of $37,000 \mathrm{ft}^{3} / \mathrm{s}$ and allowing $10,20,30$, and 40 percent of the $37,000 \mathrm{ft}^{3} / \mathrm{s}$ to bypass cross sections 


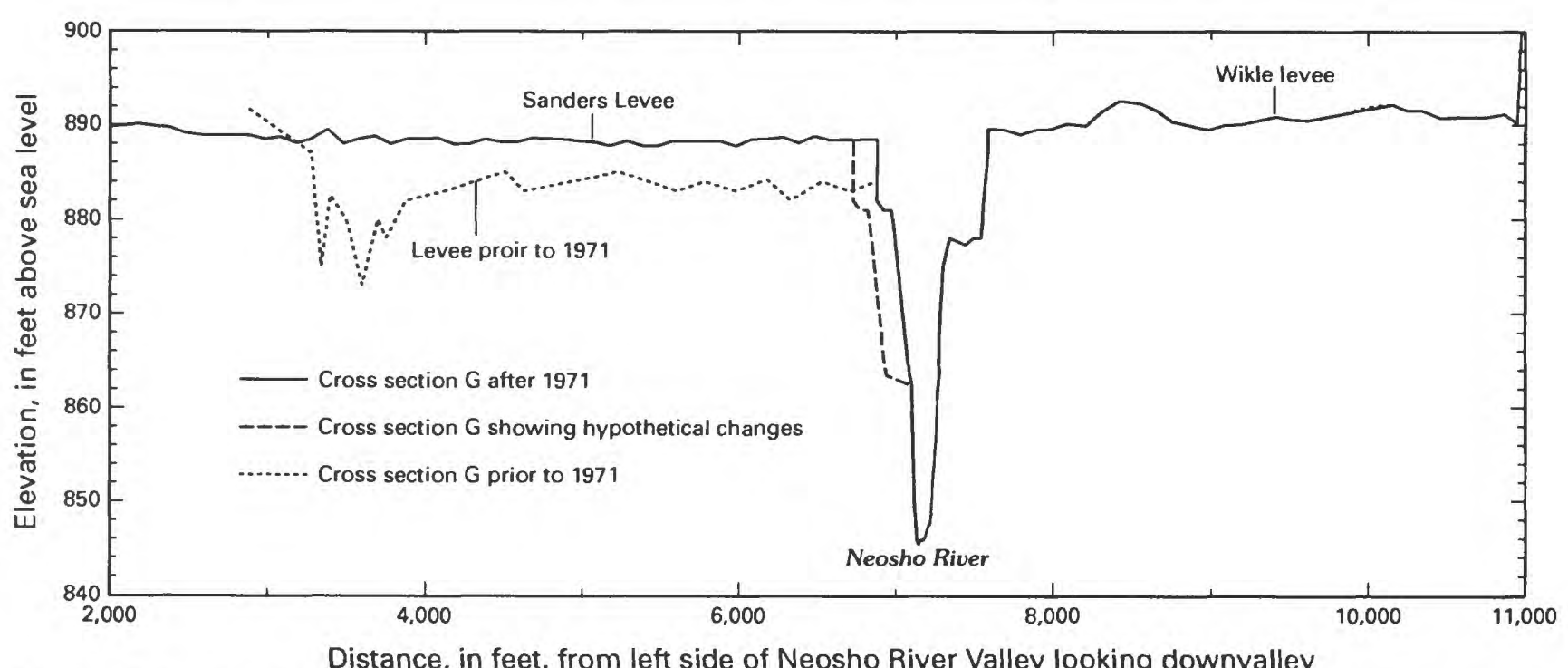

Figure 15. Land-surface elevations for cross section G before 1971, after 1971, and for hypothetical changes.

D through $\mathrm{G}$ via the hypothetical relief structure. The WSPRO model results indicate that, with each 10 -percent decrease in discharge $(10,20,30$, and 40 percent $)$, water-surface elevations at cross section $\mathrm{H}$ would decrease about 0.04 to $0.06 \mathrm{ft}(0.06,0.11,0.16$, and $0.20 \mathrm{ft}$, respectively) (table 1 , fig. 16).

A third method of decreasing water-surface elevations upstream from the new U.S. Highway 59 bridge would be to remove sediment at the new

U.S. Highway 59 bridge. Sediment has been accumulating in the vicinity of the U.S. Highway 59 opening since the bridge was constructed as indicated by a survey completed by KDOT in 1991. In 1998, KDOT estimated $100,000 \mathrm{yd}^{3}$ of sediment had been removed from the flood plain of the Neosho River in the immediate vicinity of the new U.S. Highway 59 bridge (Robert Reynolds, KDOT, written commun., 1998), increasing the cross-sectional area through the bridge opening (fig. 4). Hydraulically, this condition indicates that the new U.S. Highway 59 bridge is not creating backwater and that the narrowest cross section for this particular reach of the river is upstream from the bridge. (Water velocities upstream that are greater than velocities through the bridge opening result in sedimentation at the bridge). WSPRO model simulations were conducted for 1991 and 1998 bridge-opening conditions at discharges of 82,000 and $111,000 \mathrm{ft}^{3} / \mathrm{s}$. The removal of the sediment decreased the watersurface elevation upstream by about $0.20 \mathrm{ft}$ at discharges of 82,000 and $111,000 \mathrm{ft}^{3} / \mathrm{s}$ (table 1).
The WSPRO model also was used to simulate conditions prior to the improvement of the Sanders Levee (left bank). In this simulation, cross section $\mathrm{G}$ was eliminated, and the water was allowed to flow onto the flood plain at much smaller discharges. These model simulations indicated that the water surface would be only $0.10 \mathrm{ft}$ lower than with the Sanders Levee in place.

\section{SUMMARY}

A hydraulic analysis of the Neosho River in the vicinity of the U.S. Highway 59 crossing near Erie, southeast Kansas, was conducted using a stepbackwater model (WSPRO). Hydraulic data for this program were determined from onsite inspections and surveys, bridge plans, and topographic maps. A discharge of $37,000 \mathrm{ft}^{3} / \mathrm{s}$ (cubic feet per second) for the flood of November 4,1998 , and $82,000 \mathrm{ft}^{3} / \mathrm{s}$ for the flood of October 4-6, 1986, along with the elevation of high-water marks for those floods, were used to verify model simulations.

The section of the Neosho River in the vicinity of Erie used for the hydraulic analysis of the U.S. Highway 59 crossing is complicated by several factors, including a railroad crossing, an overflow dam, two major highway crossings (old and new U.S. Highway 59), and several levees on both sides of the river. These structures affect the backwater characteristics of 


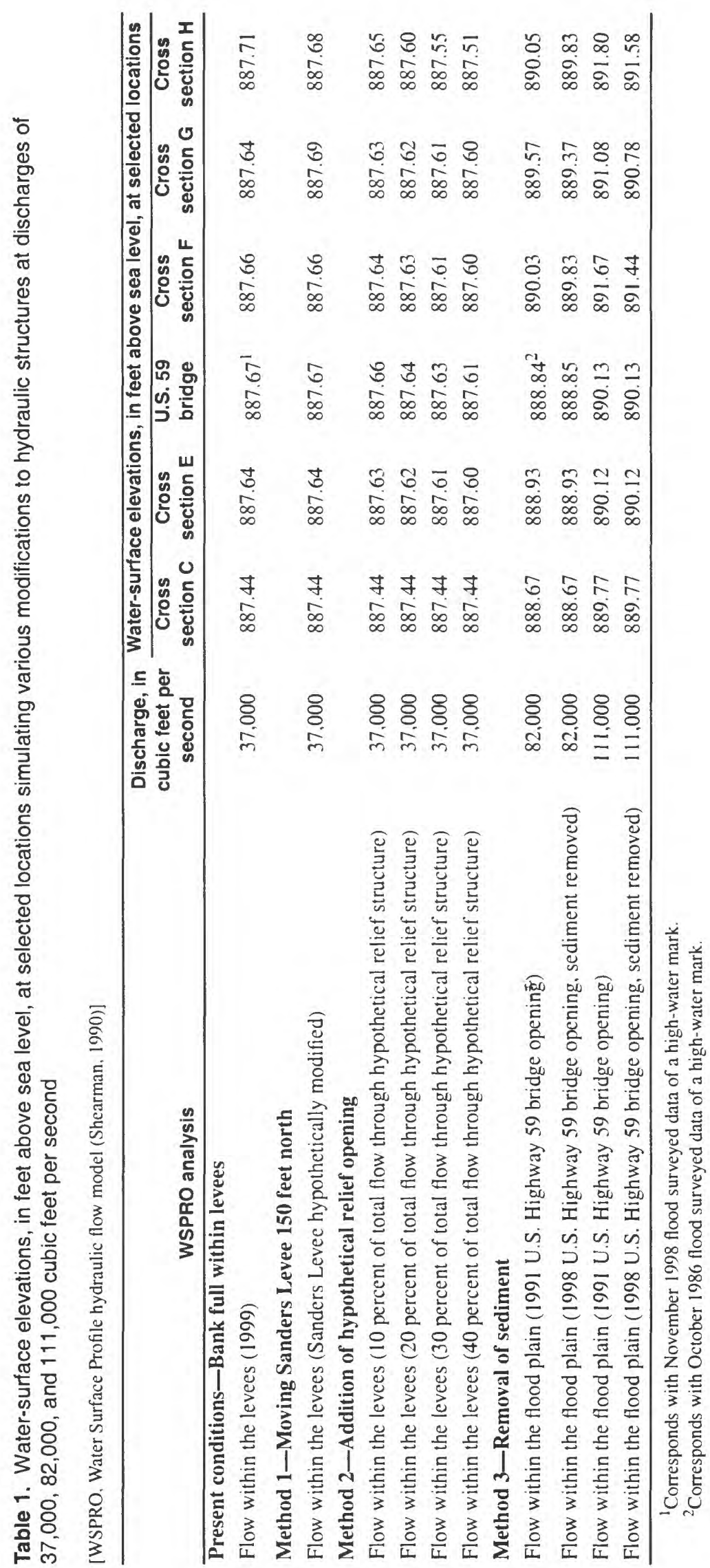




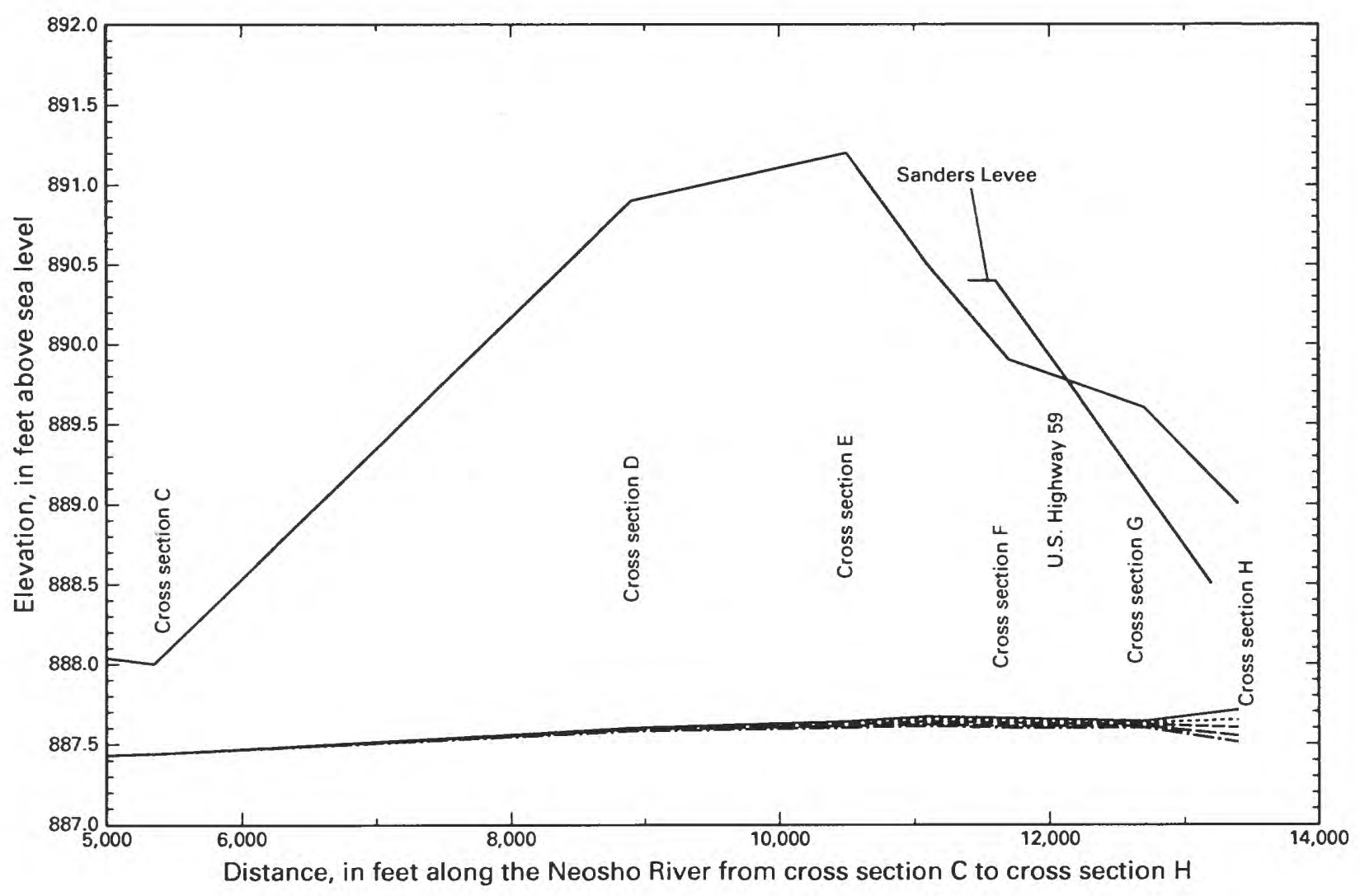

EXPLANATION

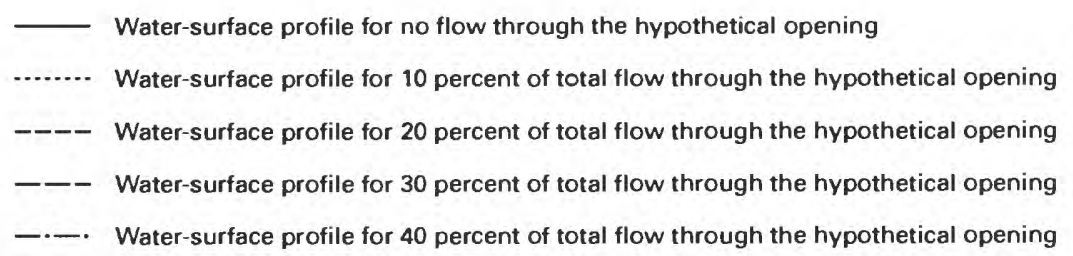

Figure 16. Simulated water-surface elevations at a discharge of 37,000 cubic feet per second for Neosho River near Erie, Kansas, for flow through a hypothetical relief structure. Location of hypothetical relief structure shown in figure 2.

the Neosho River and its tributaries in various ways that depend upon the magnitude of stream discharge. The simulations using WSPRO analyses indicate that the levees in the vicinity of the U.S. Highway 59 bridge begin to be overtopped when the Neosho River discharge nears $37,000 \mathrm{ft}^{3} / \mathrm{s}$. Water-surface elevations exceed levee elevations by as much as $0.60 \mathrm{ft}$ at a discharge of about $82,000 \mathrm{ft}^{3} / \mathrm{s}$ as the entire flood plain conveys floodwaters. At discharges of 82,000 and $111,000 \mathrm{ft}^{3} / \mathrm{s}$, the backwater from the U.S. Highway 59 bridge embankment is about 1.0 and $1.2 \mathrm{ft}$ deep for the respective discharges.

Model simulations indicate that the problem of levee overtopping upstream from the new U.S. High- way 59 bridge over the Neosho River does not have a clear solution. Various modifications to the hydraulic structures in the vicinity of the U.S. Highway 59 crossing of the Neosho River Valley were modeled using WSPRO. These modifications included enlarging the cross-sectional area of the channel by increasing the distance between the levees upstream from the new bridge, installation of a relief structure in the cutoff channel, and removal of sediment from the new bridge opening. All modifications except the hypothetical relief structure resulted in less than a $0.20-\mathrm{ft}$ decrease in water-surface elevations upstream from the U.S. Highway 59 bridge. The addition of a relief structure that conveys $10,20,30$, or 40 percent of the Sand- 
ers Levee capacity $\left(37,000 \mathrm{ft}^{3} / \mathrm{s}\right)$ would result in a $0.06-, 0.11-, 0.16-$, or $0.20-\mathrm{ft}$ decrease, respectively, in water-surface elevations upstream from the U.S. Highway 59 bridge.

\section{REFERENCES}

Cook, Flatt and Strobel Engineers, 1988, Dutton Levee district, Neosho County, Kansas, Neosho River-eligibility inspection report of non-Federal local protection project: Topeka, Kansas, prepared for the U.S. Army Corps of Engineers, 24 p.

Davidian, Jacob, 1984, Computation of water-surface profiles in open channels: U.S. Geological Survey Techniques of Water-Resources Investigations, book 3 , chap. A15, 48 p.

Federal Emergency Management Agency, 1993, Flood insurance study, city of Erie, Kansas: Washington, D.C., 16 p.
Geiger, C.O., Lacock, D.L., Putnam, J.E., Merry, C.E., and Schneider, D.R., 1988, Water resources data, Kansas, water year 1987: U.S. Geological Survey Water-Data Report KS-87-1, 492 p.

Kansas Water Resource Board, 1961, State water plan studies, Part A, Preliminary appraisal of Kansas water problems, Section 7, Neosho Unit: Topeka, Kansas, $135 \mathrm{p}$.

Matthai, H.F., 1967, Measurement of peak discharge at width contractions by indirect methods: U.S. Geological Survey Techniques of Water-Resources Investigations, book 3, chap. A4, 44 p.

Putnam, J.E., Lacock, D.L., Schneider, D.R., and Carlson, M.D., 1999, Water resources data, Kansas, water year 1998: U.S. Geological Survey Water-Data Report KS-98-1, 447 p.

Shearman, J.O., 1990, User's manual for WSPRO—a computer model for water surface profile computations: U.S. Federal Highway Administration Report No. FHWA-IP-89-027, 177 p. 